Solid Earth Discuss., https://doi.org/10.5194/se-2018-112

Manuscript under review for journal Solid Earth

Discussion started: 22 October 2018

(c) Author(s) 2018. CC BY 4.0 License.

\title{
What seismicity offshore Sicily suggests about lithosphere dynamics and microplate fragmentation models in the Central Mediterranean
}

\author{
Giancarlo Neri ${ }^{1}$, Cristina Totaro ${ }^{1}$, Barbara Orecchio ${ }^{1}$, Debora Presti ${ }^{1}$ \\ ${ }^{1}$ Department of Mathematics, Computer Sciences, Physics, and Earth Sciences, \\ University of Messina \\ Viale F. Stagno D'Alcontres, 31 \\ 98166 Messina, Italy
}

Corresponding author:

Giancarlo Neri

University of Messina,

Department of Mathematics, Computer Sciences, Physics, and Earth Sciences,

Viale F. Stagno D'Alcontres, 31

98166 Messina, Italy

email: geoforum@unime.it 
Solid Earth Discuss., https://doi.org/10.5194/se-2018-112

Manuscript under review for journal Solid Earth

Discussion started: 22 October 2018

(c) Author(s) 2018. CC BY 4.0 License.

9 Abstract

10

11 We analyze an updated dataset of earthquakes of Southern Italy, focusing in particular on

12 hypocenter locations and seismogenic stress distributions in the southern and eastearn offshores of

13 Sicily, the two sectors of the study region where seismic and geodetic information needed for

14 geodynamic modeling is still poor because of poor geometry of monitoring networks. Using

15 Bayesian non-linear methods for hypocentral locations and hypocenter error estimates we improve

16 the earthquake locations performed by more traditional linearized techniques, and this helps us to

17 make significant progress in the interpretation of seismicity and seismogenic stress distributions

18 especially where seismometric network geometry is more critical. Epicenter maps and hypocenter

19 vertical sections, together with (i) best quality focal mechanisms coming from seismic waveform

20 inversion and (ii) orientations of stress principal axes estimated by inversion of focal mechanisms,

21 help us to better recognize geodynamic engines and plate margin deformation in the study area.

22 NW-trending convergence between Africa and Eurasia is recognized as the main source of tectonic

23 stress in the study region, producing clearly detectable signatures in terms of $\sigma_{1}$ orientations also in

24 the offshore sectors of the western Ionian and the Sicily Channel. Seismicity and seismogenic stress

25 tensor highlight nearly uniform compressional dynamics related to plate convergence in the Sicily

26 Channel, in contrast to rifting and microplate divergence proposed in that sector by other 
Solid Earth Discuss., https://doi.org/10.5194/se-2018-112

Manuscript under review for journal Solid Earth

Discussion started: 22 October 2018

(c) Author(s) 2018. CC BY 4.0 License.

27 investigators. In the western Ionian, seismicity and stress inversion results reveal superposition of

28 convergence-related compression and extensional dynamics. The latter, characterized by minimum

29 compressive stress oriented SW-NE, can be related to a rifting process (opening SW-NE)

30 hypothesized by previous investigators on the basis of marine geophysics analyses performed

31 between the Alfeo-Etna and the Ionian Faults. The seismicity and seismogenic stress detected in the

32 Western Ionian show that assumptions of microplate rigidity in this area made by previous workers

33 when modeling poor geodetic data available can be inappropriate. Our findings indicate that more

34 complex rheologic models should be adopted for reconstruction of tectonic deformation and

35 microplate relative motions in the Central Mediterranean region.

36 
Solid Earth Discuss., https://doi.org/10.5194/se-2018-112

Manuscript under review for journal Solid Earth

Discussion started: 22 October 2018

(c) Author(s) 2018. CC BY 4.0 License.

39 The progressive increase in the last few decades of available data concerning crustal motions and

40 strains has allowed the researchers to intensify the investigations on the geometry, kinematics and

41 dynamics of the plates, microplates and tectonic units in the Mediterranean region, in particular in

42 the central part of it corresponding to south Italy and the Tyrrhenian and Ionian seas (Figs 1 to 3). In

43 spite of the progresses made in the geophysical data acquisition and analysis, different views still

44 exist, however, concerning the fragmentation of lithosphere and microplate architecture and kinematics in this portion of the Africa-Eurasia convergent margin (see e.g. Anderson and Jackson, 1987; Oldow et al., 2002; Battaglia et al., 2004; Serpelloni et al., 2007; Nocquet, 2012; Sani et al., 2016, among others). A wide description of the debate and state of art of knowledge on these topics is given in Sect. 3.

50 The relatively large number of models and hypotheses still resisting to checks by new data and analyses is mainly due to poor distribution of GPS stations in the offshore areas and to the often concomitant assumption of internally rigid crustal blocks adopted when modeling the plate/microplate kinematics. The puzzle is complicated by too weak evidence of potential microplate boundaries furnished by earthquake activity resulting scarce as regard to (i) number and energy of seismic events and (ii) geometrical continuity of seismolineaments. Other kinds of data and information from geophysics and geology have not, yet, solved the ambiguities (Oldow et al.,

57 2002; D'Agostino et al., 2008; Nocquet, 2012).

In the present study we use an updated set of earthquake data with the purpose of contributing to the current debate on microplate architecture and dynamics in the Central Mediterranean, paying particular attention to a few sectors offshore Sicily, namely the Western Ionian and the Sicily Channel (WI and SC in Fig. 4a), resulting of crucial relevance for the solution of some still existing 
Solid Earth Discuss., https://doi.org/10.5194/se-2018-112

Manuscript under review for journal Solid Earth

Discussion started: 22 October 2018

(c) Author(s) 2018. CC BY 4.0 License.

uncertainties. The potentialities of the methods of seismological analysis we have planned to use, in

64 part of recent conception and in all cases already proven to be effective in the study region (see e.g.

65 Neri et al., 2005; Billi et al., 2010; D'Amico et al., 2010; Presti et al., 2013), make us confident that the above declared goal of the investigation may be reached.

67

68

69

70

71

\section{Geodynamic frame of the study region}

In the Mediterranean region (Fig. 1), after a long period between Late Paleogene and Neogene of Africa NW-ward subduction beneath Eurasia, subduction has almost ceased (Billi et al., 2011). With the progression of Africa-Eurasia convergence, a tectonic reorganization of the plate boundary has started to accomodate contraction, in particular contractional deformation in several segments of the boundary (such as Sicily) has shifted from the former subduction zone to the margins of the back-arc oceanic basins (Fig. 2). The tectonic reorganization of the boundary is still strongly controlled by the inherited tectonic fabric and rheological attributes, which are strongly heterogeneous along the boundary.

In Italy (Fig. 1) the Neogene convergence and associated subduction between Africa and Eurasia resulted in the NW-trending Apennine and the W-trending Maghrebian fold-thrust belts in peninsular Italy and Sicily, respectively (Malinverno and Ryan, 1986). The two belts are connected through the Calabrian Arc (Minelli and Faccenna, 2010), below which a narrow remnant of the former subducting slab seems to be still active, but close to cessation (Neri et al., 2009; 2012; Orecchio et al., 2015; Chiarabba and Palano, 2017).

Contraction in Sicily is, at present, mainly accomodated at the rear of the fold-thrust belt, in the southern Tyrrhenian sea (Fig. 2), where a series of contractional earthquakes located in an E- 
Solid Earth Discuss., https://doi.org/10.5194/se-2018-112

Manuscript under review for journal Solid Earth

Discussion started: 22 October 2018

(c) Author(s) 2018. CC BY 4.0 License.

trending belt between Ustica and Eolian islands have been recorded in the last decades (Pondrelli et al., 2004; Billi et al., 2007; Presti et al., 2013; Orecchio et al., 2017). Toward the east, the compressional seismic belt is delimited by the seismically active Tindari Fault System (TFS in Fig. 2), to the east of which, both earthquakes and GPS data provide evidence for an ongoing extensional tectonics possibly connected with the residual subduction beneath the Calabrian Arc and related back-arc extension (Palano et al., 2015b). The age for the onset of the ongoing contraction in the south-Tyrrhenian margin is unknown, but the cessation of volcanism at Ustica (i.e., the already mentioned volcanic island located along the south-Tyrrhenian contractional belt) during Middle-Late Pleistocene may be connected with the onset of contractional tectonics in this area. This age corresponds approximately with the cessation of contractional displacements along the outermost Gela nappes in southern Sicily (Fig. 2; Ghisetti et al., 2009).

The plate margins strongly simplified in Fig. 1 have undergone significant changes over time as a consequence of the above processes and of the whole geodynamic activity occurring in the Mediterranean region. Recent investigations performed thanks to the increasing set of geodetic data available have brought the researchers to propose different scenarios of microplate fragmentation and reorganization along the boundary, in particular along the south Italy part of the boundary (see references quoted in the introduction). The next section presents a list of microplate architecture scenarios proposed in the most relevant literature and evidences the doubts and open questions still exixting in the scientific community concerning the microplate geometry and kinematics in the Italian part of the Africa-Eurasia plate boundary. 
Solid Earth Discuss., https://doi.org/10.5194/se-2018-112

Manuscript under review for journal Solid Earth

Discussion started: 22 October 2018

(c) Author(s) 2018. CC BY 4.0 License.

114 Two of the former studies reporting on the possible fragmentation of lithosphere in the Italian

115 portion of the Africa-Eurasia boundary were those by Anderson (1987) and Anderson and Jackson

116 (1987). These authors explained the focal mechanisms and related slip vectors of the most

117 significant earthquakes located around the Adriatic sea assuming that a rigid block (Adria) is

118 independent from the two main plates and rotates anticlockwise around a pole located in northern

119 Italy (Fig. 3b). They, however, remarked the main weakness of their model represented by the lack

120 of significant seismicity at the presumed southern border of Adria microplate. Oldow et al. (2002)

121 and Oldow and Ferranti (2006) proposed a quite different architecture of microplates and blocks in

122 the Italian region, with a southeastern 'Adria' block separated from a northwestern 'Adria' one by a

123 line crossing south Italy and the northern Adriatic sea (Fig. 3c).

Closer to Anderson and Jackson’s (1987) reconstruction, Battaglia et al. (2004) explained GPS data re-introducing an Adriatic domain strictly corresponding to the Adriatic sea, independent from Africa and Eurasia, but separated in two blocks, Northern and Southern Adria, confining in the Central Adriatic sea (Fig. 3d). Serpelloni et al. (2007) proposed an even more complex fragmentation of the whole plate boundary, suggesting in particular that a Sicilian domain is moving independently from Africa according to the presence of a right-lateral and extensional decoupling zone corresponding to the Tunisia-Libya and Sicily Channel deformation zone (Fig. 3e). According to the same authors, the tectonics and kinematics of the Italian region are further complicated by Ionian oceanic lithosphere subducted beneath Calabria and by Adria independent microplate rotating anticlockwise with respect to Africa and Eurasia main plates. Serpelloni and coworkers remark, however, that lack of GPS data and poor seismic network geometry in wide offshore sectors like the Ionian basin leave some uncertainties in the geodynamic modeling, in particular they suspect (but cannot prove) the existence of an independent Ionian microplate rotating counterclockwise between Africa and Adria plates (Fig. 3e). In this connection the same authors leave open the question "where strain locates between Hyblean and Apulia domains?". 
Solid Earth Discuss., https://doi.org/10.5194/se-2018-112

Manuscript under review for journal Solid Earth

Discussion started: 22 October 2018

(c) Author(s) 2018. CC BY 4.0 License.

D'Agostino et al. (2008) interpreted their GPS and earthquake slip data (i) by limiting the anticlockwise rotating rigid Adria microplate to the northern Adriatic region and (ii) by introducing a larger, newly defined microplate to the south, including the Apulia promontory, the Ionian sea and the Hyblean region in southern Sicily (Fig. 3f). According to these authors, the hypothesis of Hyblean region belonging to such a hypothetical microplate would be supported by apparently low GPS-derived deformation in the western Ionian. In any case the authors admit that lack of data in the Ionian offshore of Sicily does not allow decisive checking of their assumption of two rigid microplates located between Africa and Eurasia, one rotating clockwise (Apulia-Ionian-Hyblean) and the other anticlockwise (Adria).

More recently, by analysis of a relatively long period of 18 years of GPS observations, Palano et al. (2012) supported the thesis of an Hyblean block independent with respect to Africa and Apulia (Fig. 3g-h). They located the regional contraction existing between the Tyrrenian and Hyblean blocks in two distinct belts identified in the northern Sicily offshore (Ustica-Eolie) and across the Sicily front (Sicilian basal thrust according to Lavecchia et al., 2007). The authors discussed also the role played by the Ionian domain and suggested two possible scenarios, one assuming that the Ionian is rigidly connected with the Hyblean block (Fig. 3g), the other assuming that the Ionian domain diverges from the Hyblean block and moves to northeast wrt to Eurasia (Fig. 3h). They concluded that the lack of islands (i.e. of data) in the Ionian offshore does not allow to make a choice among these scenarios. Based on the analysis of GPS velocities and earthquake focal mechanisms in the Central and Eastern Mediterranean, Pérouse et al. (2012) proposed that the area including the Hyblean Plateau, the Ionian basin, the Apulian peninsula, the south Adriatic sea and the Sirte plain may be considered as a single rigid block rotating clockwise wrt Africa, inducing an opening of a couple of $\mathrm{mm} / \mathrm{yr}$ in the Sicily Channel - Pelagian rift (Fig. 3i). The same authors, similar to D'Agostino et al. (2008 and 2011), suggested that the 2-2.5 mm/yr slow trenchward motion of the Calabrian Arc wrt to the Apulian-Ionian-Hyblean-Sirte domain may be explained in terms of 
Solid Earth Discuss., https://doi.org/10.5194/se-2018-112

Manuscript under review for journal Solid Earth

Discussion started: 22 October 2018

(c) Author(s) 2018. CC BY 4.0 License.

ultraslow residual subduction or, alternatively, by pure gravitational collapse into an inactive subduction scenario. More recently, the Oldow et al's (2002) scheme of Fig. 3c was reproposed with modifications by Sani et al. (2016) (Fig. 3j).

In his review of papers and investigations regarding the crustal kinematics in the Mediterranean region, Nocquet (2012) drew the conclusion that it is quite difficult to state from the available data and analyses where stable Africa finishes and other eventual blocks like Apulia begin in the Central Mediterranean area at the longitude of Italy. In a very recent analysis performed by integration of multibeam, seismic reflection, magnetic and gravity data, Polonia et al. (2017) have concluded that: (i) tearing at the southwestern edge of the SEward-retreating Calabria subduction slab may be the deep source of shallow deformation detected in correspondence of the transtensional Ionian Fault in the Ionian basin (Fig. 2); (ii) the NW-SE trending belt comprised between the Ionian Fault and the Alfeo-Etna Fault (Fig. 2) hosts a rifting zone opening SW-NE where serpentinite diapirs have been identified by the authors. On their hand, Gutscher et al. (2017), by analysis of multi-beam bathymetric data and seismic profiles, proposed the Alfeo-Etna right-lateral fault system as shallow tectonic expression of the retreating slab tear or STEP fault. In the view of these authors some sinistral lateral component appearing in the southeasternmost part of the Ionian Fault should exclude the latter as potential expression of the STEP fault. Another major fault system marking the transition between the Ionian basin and the Hyblean plateau, e.g. the Malta escarpment (Fig. 2), shows not to be currently active along most of its lenght and shows signs of recent faulting only in its northernmost segment (see, e.g., Argnani, 2009; Gutscher et al., 2016). West of the Malta escarpment (Fig. 2), a detailed analysis of reflection profiles and stratigraphic and structural data allowed Cavallaro et al. (2016) to evidence clear time evolution from tensional to compressive regimes in the Sicily Channel WNW-trending main structural system, until its present-day behaviour as transcurrent fault system under compression due to NW-SE Africa-Eurasia convergence. Cavallaro et al. (2016) proposed, in particular, that local volcanism stopped in late 
Solid Earth Discuss., https://doi.org/10.5194/se-2018-112

Manuscript under review for journal Solid Earth

Discussion started: 22 October 2018

(c) Author(s) 2018. CC BY 4.0 License.

192 Miocene and Miocene-time normal faults were reactivated during Zanclean-Piacenzian age as right-

193 lateral strike-slip faults.

195 The above description of scenarios and findings highlights uncertainties still existing concerning the

196 plate boundary evolution and the present-day architecture and kinematics of microplates and lithospheric blocks in the Central Mediterranean. Poor distribution of GPS and seismic networks in the offshore sectors of Western Ionian and Sicily Channel cause most of these uncertainties (see, among others, the already quoted papers by Serpelloni et al., 2007; D’Agostino et al., 2008; Palano et al., 2012; Nocquet, 2012). In the present study, we start with a regional-scale analysis of recent seismicity updated to the end of 2016. Then, we focus on the most critical sectors of the Western Ionian and the Sicily Channel where new seismic data and improvements of knowledge concerning earthquake and seismogenic stress distribution can help answering the questions left open by the previous investigations.

\section{Data, methods of analysis and results}

We have taken from the Italian national seismic catalog (http://istituto.ingv.it/l-ingv/archivi-ebanche-dati/) and from the databases of the local seismic networks operating in Sicily and Calabria (Orecchio et al., 2011) the data of the earthquakes of magnitude over 2.5 that occurred between

2121981 and 2016 at depths less than $100 \mathrm{~km}$ in the area $10^{\circ}-20^{\circ} \mathrm{E} 35^{\circ}-41^{\circ} \mathrm{N}$ bounded by the dashed

213 rectangle in Fig. 4a. We have selected only the events for which a minimum of $15 \mathrm{P}+\mathrm{S}$ arrival times

214 were available. For these events we have performed hypocenter locations by the standard, linearized

215 location method Simulps (Evans et al., 1994) and the 3D seismic velocity structure proposed for the

216 study region by Orecchio et al. (2011). The epicenter maps of the earthquakes located with this

217 procedure, corresponding to different hypocenter depth ranges, are shown in Fig. 4b-d. Then, we 
Solid Earth Discuss., https://doi.org/10.5194/se-2018-112

Manuscript under review for journal Solid Earth

Discussion started: 22 October 2018

(c) Author(s) 2018. CC BY 4.0 License.

218 have selected from the literature and the international catalogs all the fault-plane solutions estimated

219 by waveform inversion for the earthquakes of magnitude over 2.5 occurring in the period 1977-

2202016 at depths less than $70 \mathrm{~km}$ in the same area of the above locations (dashed rectangle of Fig. 4).

221 The map of these fault-plane solutions is shown in Fig. 5, the list of focal parameters is furnished in

222 Table A1, Appendix A.

224 A new step of analysis was that of using the Bayesian non-linear location algorithm named Bayloc

225 (Presti et al., 2004 and 2008) for relocation of the earthquakes located by Simulps in the two sectors indicated by WI (Western Ionian) and SC (Sicily Channel) in Fig. 4a. The same 3D local velocity structure by Orecchio et al. (2011) has been used also in this new phase of analysis. Starting from seismic phase arrival times at the recording stations, Bayloc computes for an individual earthquake a probability cloud marking the hypocenter location uncertainty. Then, Bayloc estimates the spatial distribution of probability relative to a set of earthquakes by summing the probability densities of the individual events. This method has been shown to help detection of the seismogenic structures through better hypocenter location and more accurate estimation of location errors compared to

233 linearized methods (Presti et al., 2008) but computational reasons make its application easier when carried out in small areas (Presti et al., 2004). For this reason we have used Simulps for locating the whole dataset of events of Fig. 4 and Bayloc for locations in the two sectors of more crucial relevance in the present study, namely WI and SC. Details on the methodological aspects of Bayloc can be found in the above quoted papers. The epicenter maps and hypocenter vertical sections obtained by Bayloc are shown in the Figs 6 and 7. Epicenter and hypocentre errors of the order of 3 $\mathrm{km}$ and $5 \mathrm{~km}$ have been estimated for the earthquakes of Sector WI, rising to values of $4 \mathrm{~km}$ and 9 $\mathrm{km}$ in Sector SC.

242 The information furnished in the bibliographic sources of the focal mechanisms of Fig. 5 indicates that these focal mechanisms should be characterized by fault parameter errors of the order 10-15 
Solid Earth Discuss., https://doi.org/10.5194/se-2018-112

Manuscript under review for journal Solid Earth

Discussion started: 22 October 2018

(c) Author(s) 2018. CC BY 4.0 License.

degrees, then generally smaller than errors of focal mechanisms computed by inversion of P-onset polarities in areas of critical network geometry like ours (D’Amico et al., 2011; Presti et al., 2013; Musumeci et al., 2014). This level of uncertainty makes the dataset of Fig. 5 suitable for application of the method by Gephart and Forsyth (1984) and Gephart (1990) for calculating the seismogenic stress tensor directions in the study region. This method searches for the stress tensor showing the best agreement with the available focal mechanisms (FMs). Four stress parameters are calculated: three of them define the orientations of the main stress axes; the other is a measure of relative stress magnitudes, $\mathrm{R}=\left(\sigma_{2}-\sigma_{1}\right) /\left(\sigma_{3}-\sigma_{1}\right)$, where $\sigma_{1}, \sigma_{2}$ and $\sigma_{3}$ are the values of the maximum, intermediate and minimum compressive stresses, respectively. In order to define discrepancies between the stress tensor and observations (FMs), a misfit variable is introduced: for a given stress model, the misfit of a single focal mechanism is defined as the minimum rotation about any arbitrary axis that brings one of the nodal planes, and its slip direction and sense of slip, into an orientation that is consistent with the stress model. Searching through all orientations in space by a grid technique operating in the whole space of stress parameters, the minimum sum of the misfits of all FMs available is found. The confidence limits of the solution are computed by a statistical procedure described in the papers by Parker and Mc Nutt (1980) and Gephart and Forsyth (1984). The size of the average misfit corresponding to the best stress model provides a guide as to how well the assumption of stress homogeneity is fulfilled (Michael 1987). In the light of results from a series of tests carried out by

262 Wyss et al. (1992) and Gillard et al. (1996) to identify the relationship between FM uncertainties and average misfit in the case of uniform stress, we will assume that the condition of homogeneous stress distribution is fulfilled if the misfit, $\mathrm{F}$, is smaller than $6^{\circ}$, and that it is not fulfilled if $\mathrm{F}>9^{\circ}$. In the range $6^{\circ}<\mathrm{F}<9^{\circ}$, the solution is considered as acceptable, but may reflect some heterogeneity. For the application of Gephart and Forsyth's (1984) method in the present study, we have focused on the area contoured by the thin line in Fig. 5 including southern Sicily, the Sicily Channel and the

268 Western Ionian, e.g. the sectors where the knowledge of seismogenic stress distributions is poorer 
Solid Earth Discuss., https://doi.org/10.5194/se-2018-112

Manuscript under review for journal Solid Earth

Discussion started: 22 October 2018

(c) Author(s) 2018. CC BY 4.0 License.

than elsewhere in the region (see, among others, Totaro et al., 2016). The stress inversion results obtained in the present study are reported in Table 1 and Fig. 8.

\section{Discussion}

The epicenter and focal mechanism maps of Figs 4 and 5 evidence two main features of the regional seismicity already known from previous investigations. The first of these features is represented by clear spatial grouping of shallow earthquakes in correspondence of the Apennine-Maghrebian chain from the southern Apennines to Sicily (Fig. 4c) marking response to perpendicular-to-chain extensional stress (Fig. 5). The second feature is the nearly east-trending compressional seismic belt appearing from Figs $4 \mathrm{c}$ and 5 in the southern Tyrrhenian sea offshore Sicily, ending to east in the Eolian Islands area where the orientation of the belt and the faulting style clearly change to NW-SE and dextral strike-slip, respectively. Moderate activity can be detected from the same figures in the Sicily Channel (compressional regime) and in the Western Ionian sea (compression prevailing but not exclusive). Also, a clear drop of activity can be noted in the Ionian offshore of Southern Calabria (Figs 4c and 5). These features confirm the picture of regional seismicity given by the previous investigators who distinguished a compressional domain of the southern Tyrrhenian and Ionian seas due to Africa-Eurasia NW-trending convergence and an extensional one along the Apennine-Maghrebian chain due to different factors in the different segments of the chain (see e.g., Presti et al., 2013; Totaro et al., 2016; Orecchio et al., 2017).

The previous sections have described the efforts made by many investigators to identify opening zones between diverging microplates in the Sicily Channel and the Ionian sea with the purpose of explaining the space variations of crustal motions measured by GPS networks in the Central Mediterranean region. Lack of data in wide offshore sectors is the main reason why the debate on 
Solid Earth Discuss., https://doi.org/10.5194/se-2018-112

Manuscript under review for journal Solid Earth

Discussion started: 22 October 2018

(c) Author(s) 2018. CC BY 4.0 License.

microplate geometry and kinematics in the region is still open. The results of the present study may, in our opinion, furnish a useful contribution to this debate. Stress tensor inversion of earthquake fault-plane solutions in the area including Southern Sicily, the Sicily Channel and the Western Ionian sea (Fig. 8a, set ALL) reveals moderate stress heterogeneity (F-value of $8.3^{\circ}$ ) around a best model of stress characterized by a sub-horizontal, NW-trending $\sigma_{1}$ clearly reconductible to AfricaEurasia convergence (Fig. 8a and Table 1). Starting from this result, we have sub-divided the dataset of focal mechanisms of Fig. 8a in tens of subsets according to the epicenter distribution, focal depth and magnitude of the earthquakes, in order to search for subsets satisfying the condition of stress homogeneity. As explained in the previous Section, this condition can be considered reasonably satisfied in the present study when the F-value of inversion is lower than $6^{\circ}$. In order to guarantee the significance of stress computations in the different subsets we have decided to fix a minimum number of 20 earthquakes (= focal mechanisms) for the creation of the individual subset. The stress inversion results obtained after the first step of partitioning of the dataset into different subsets indicated new strategies of partitioning or data grouping. For sake of conciseness, we do not report the stress inversion results obtained for all the subsets investigated, we only report in Fig. 8 and Table 1 the results that we consider more meaningful, that is, able to better outline the stress patterns and tectonic features in the study area.

Fig. $8 \mathrm{~b}$ and Table 1 (lines $\mathrm{W}$ and $\mathrm{E}$ ) report the stress inversion results obtained by subdividing the

314 study area in two sectors $\mathrm{W}$ and $\mathrm{E}$ located, respectively, west and east of a NW-trending separation

315 line indicated as $\mathrm{AB}$ in the same Fig. 8b. A F-value of $5.9^{\circ}$ shows that stress is homogeneous or 316 close to homogeneity in the $\mathrm{W}$ sector (Table 1). The best model of stress in this western sector is similar to that obtained by inversion of the mechanisms of the whole study area (Fig. $8 \mathrm{a}$ and Table

318 1). The $95 \%$ confidence limits of stress orientations in $\mathrm{W}$ (Fig. 8b) show an acceptable level of constraint of $\sigma_{1}$ orientation. On the other hand, the confidence area of $\sigma_{3}$ orientation in the same sector is relatively large and extends from vertical to SW-NE horizontal direction, i.e. $\sigma_{3}$ and $\sigma_{2}$ are 
Solid Earth Discuss., https://doi.org/10.5194/se-2018-112

Manuscript under review for journal Solid Earth

Discussion started: 22 October 2018

(c) Author(s) 2018. CC BY 4.0 License.

unconstrained on the SW-NE vertical plane, plausibly in relation to co-existence of reverse and strike-slip seismic faulting in the study volume under SE-NW compression due to plate convergence. These results are in good agreement with the geostructural and geodynamic reconstruction of this area proposed by Cavallaro et al. (2016) who evidenced, in particular, long term evolution from tensional to compressive regimes in the Sicily Channel until the present-day state of compression led by NW-SE Africa-Eurasia convergence.

The inversion of the fault-plane solutions available in sector E of Fig. 8b leads to a F-value of $8.3^{\circ}$ indicating a certain degree of stress heterogeneity as already inferred from the analysis of the whole dataset of Fig. 8a. The best model of stress in sector E (Fig. 8b and Table 1) is quite similar to those of sets ALL and W (Table 1), and this indicates that NW-SE compression from plate convergence is again detectable in this eastern part of the study area. However, the $95 \%$ confidence limits of stress orientations in E reveal that $\sigma_{1}$ orientation is practically unconstrained from horizontal NW-SE to vertical, and this leads us to suppose that some extensional process opening SW-NE acts together with NW-trending plate convergence in this sector.

By comparing the location of the separation line between the $\mathrm{E}$ and $\mathrm{W}$ domains of Fig. $8 \mathrm{~b}$ with the structural map of Fig. 2 we can note that the separation line approximately corresponds with the location of the Alfeo-Etna Fault. Again, by comparing the Bayloc's epicenter distribution of the earthquakes shallower than $30 \mathrm{~km}$ in Sector WI (Fig. 6c) with the structural map of Fig. 2 we may note (i) a certain degree of activity in correspondence with the northern segment of the Malta escarpment, the only considered active in this structural system by several authors (see, e.g., Argnani, 2009; Gutscher et al., 2016), (ii) a clear belt of activity trending NW-SE between the

344 Alfeo-Etna and the Ionian faults and (iii) a drop of seismicity going to NE across the Ionian Fault. In the $30-70 \mathrm{~km}$ depth range (Fig. 6d) there is no seismicity in correspondence with the Malta escarpment and most of seismic activity is dispersed around the Ionian Fault. The SW-NE vertical 
Solid Earth Discuss., https://doi.org/10.5194/se-2018-112

Manuscript under review for journal Solid Earth

Discussion started: 22 October 2018

(c) Author(s) 2018. CC BY 4.0 License.

section of Fig. $6 \mathrm{~b}$ highlights that sesmicity is as shallow as $20 \mathrm{~km}$ west of the Alfeo-Etna Fault but

deepens to depths of the order of $40 \mathrm{~km}$ between the Alfeo-Etna and the Ionian faults, and remains

stable at this depth level for several tens of $\mathrm{km}$ around the Ionian Fault. In the same vertical section the presence of sesmic activity can also be noted in the upper $20 \mathrm{~km}$ halfway between the AlfeoEtna and the Ionian faults (AEF and IF).

Previous investigators (see, e.g., Polonia et al., 2011; 2016; Palano et al., 2015b) have proposed that the Ionian fault zone corresponds with the southwestern edge of the Ionian subducting slab dipping to NW and presumably still affected by slow SE-ward residual rollback. The Ionian fault zone would represent the shallow expression of a STEP fault (Polonia et al., 2016). The above commented epicenter and hypocenter distributions of Fig. 6 support this interpretation, evidencing however that the dislocation process between the subducting slab (northeast) and the adjacent lithosphere (southwest) is distributed over a relatively wide zone probably because the subduction and slab rollback kinematics are very slow and do not mimic fast STEP dynamics (Gallais et al., 2013; Orecchio et al., 2014). The earthquake activity detected in the upper $20 \mathrm{~km}$ halfway between the Alfeo-Etna and Ionian faults (Fig. 6b) occurs in a NW-trending highly heterogeneous and fractured zone identified by Polonia et al. (2017) as the site of a rifting process with SW-NE opening direction where serpentinite diapirs rise from deeper depths. This extensional process can be a cause of stress heterogeneity evidenced by stress inversion in the E domain of Fig. $8 \mathrm{~b}$ where SW-NE extension appears to be superimposed to NW-SE compression related to Africa-Eurasia convergence. The rifting process identified in this part of the Ionian sea by Polonia et al. (2017) may, therefore, contribute to explain our results from analysis of seismicity and stress inversion of earthquake fault-plane solutions. This interpretation appears also to match well with the space variation of GPS vectors in Sicily and Calabria (Fig. 9; vector data from Palano et al., 2012) showing clear rotation of crustal motions when crossing the onshore prolongation of the NWtrending zone between the Alfeo-Etna and Ionian faults. Having more than 20 focal mechanisms in 
Solid Earth Discuss., https://doi.org/10.5194/se-2018-112

Manuscript under review for journal Solid Earth

Discussion started: 22 October 2018

(c) Author(s) 2018. CC BY 4.0 License.

the NW-trending zone where Polonia et al. (2017) detected the rifting process, we have performed a

374 stress inversion run in this zone (RZ in Fig. 8c). The results (shown in the same Fig. 8c and in Table

375 1) are similar to those obtained in the E domain of Fig. $8 b$ and confirm our hypothesis of combination of NW-SE compression due to plate convergence and SW-NE rifting. We have also attempted to detect possible depth variations of the stress field in this rifting zone RZ and found that the convergence-related compression seems to prevail at depths deeper than $30 \mathrm{~km}$, while the combination of the two stress factors appears clearer at shallower depth. However, this latter result must be considered as uncertain or highly preliminary because the number of data available in the 0-30 $\mathrm{km}$ and $30-70 \mathrm{~km}$ depth ranges is 15 and 12 , respectively, then lower than the threshold of 20 adopted in this work for stress inversion. We do not report these latter results in graphical and numerical form, we wait for future analyses with more data before drawing conclusions on the depth variation of stress in the rifting zone of Polonia et al. (2017). We conclude our discussion on stress inversion results by remarking that partitioning of the dataset according to earthquake magnitude has not evidenced any relevant change of stress or variation of heterogeneity level among subsets. An implication of this result is that a quite frequent situation documented since decades in the literature is not observed in the case of our dataset: we specifically refer to the situation of stronger earthquakes marking a uniform regional stress locally disturbed, however, by smaller scale stress heterogeneities marked by weaker events (see, e.g., Rebaï et al., 1992; Christova, 2015).

The Bayloc's maps of epicenters in Sector SC (Fig. 7) show that seismicity is mainly located in correspondence with a ca. NNE-SSW trending fault system crossing the WNW-ESE Pelagian rift area. The depths of these events cover all the range of investigation of our analysis, i.e. $0-70 \mathrm{~km}$. The seismic activity of this NNE-SSW trending fault system covering this relatively large depth range has already been detected by previous investigators (Calò and Parisi, 2014). Our results show also that some activity occurs in the Hyblean corner of Sicily and south of it, but in this case the 
Solid Earth Discuss., https://doi.org/10.5194/se-2018-112

Manuscript under review for journal Solid Earth

Discussion started: 22 October 2018

(c) Author(s) 2018. CC BY 4.0 License.

seismicity is shallow and never exceeds the depth of $30 \mathrm{~km}$. Minor activity is located in

400 correspondence with the fault system of the Pelagian rift. These results, together with the nearly

401 homogeneous stress tensor marking SE-NW plate convergence in sector W of Fig. 8b, do not

support active rifting in the Sicily Channel. In other words our results do not support the hypothesis

of microplate separation and divergence in the Sicily Channel advanced in previous works based on analysis of poorly distributed geodetic data and microplate rigidity assumptions (see, e.g., D'Agostino et al., 2008; Perouse et al., 2012). On the other hand, our results match well with the results recently obtained in the same area by detailed analysis of reflection profiles and stratigraphic and structural data indicating clear time evolution from tensional to compressive regimes in the Sicily Channel WNW-trending main structural system, until its present-day behaviour as transcurrent fault system under compression due to NW-SE Africa-Eurasia convergence (Cavallaro et al., 2016). According to these authors, Miocene-time extensional structures of the Sicily Channel WNW-trending structural system were reactivated during Zanclean-Piacenzian age as right-lateral

412 strike-slip faults under convergence-related compression.

414 If we re-enlarge the frame of analysis to include the southern Tyrrhenian region (Fig. 9) we find 415 additional signature of the SE-NW Africa-Eurasia convergence in the southern Tyrrhenian easttrending compressional belt located offshore northern Sicily (see also Presti et al., 2013 and Totaro et al., 2016 for stress orientations in the southern Tyrrhenian seismic belt). On this scale of analysis our results match well with the very recent Nijholt et al's (2018) conclusion according to which in

419 this south-central part of the Mediterranean region "the Calabrian arc is now further transitioning towards a setting dominated by Africa-Eurasia plate convergence, whereas during the past 30 Myrs slab retreat continually was the dominant factor". Also, our investigation leads us to evidence that:

422 (i) perpendicular-to-convergence opening in the Ionian sea (between the Alfeo-Etna and Ionian faults) introduces some seismogenic stress heterogeneity in the eastern compartment of our stress inversion area (Figs 8b, 8c and 9); (ii) residual, very slow subduction and SE-ward rollback of the 
Solid Earth Discuss., https://doi.org/10.5194/se-2018-112

Manuscript under review for journal Solid Earth

Discussion started: 22 October 2018

(c) Author(s) 2018. CC BY 4.0 License.

Ionian lithosphere northeast of the Ionian Fault reduces convergence-related compression in the shallow Ionian offshore of southern Calabria and causes there a detectable drop of seismicity indicated by the arrow in Fig. 4c. This process of reduced compression can also influence stress parameters in this sector with particular reference to the Ionian offshore of Calabria, but with the data available we cannot analyze this aspect in a greater detail. We look at a future availability of additional data in the eastern sector of Fig. $8 \mathrm{~b}$ to explore in a greater detail the local space variations of stress and the contributions by the different tectonic factors.

Our results may contribute to answer some questions put by previous investigators such as, for example, Serpelloni et al. (2007) (where strain locates between Hyblean and Apulia domains?) or Palano et al. (2012) (is Ionian rigidly connected with the Hyblean block or diverging from it and moving to northeast wrt to Europe?). Our results allow us to state that (i) the Western Ionian is a main site of strain release between Hyblean and Apulia domains and (ii) the Ionian is not "rigidly connected with the Hyblean block". Following the reasoning of Palano et al. (2012) who concluded with the proposal of two alternative scenarios reported in our Fig. 3g-h, we tend to favour the hypothesis of a Ionian block diverging from the Sicilian-Hyblean-Malta block (3h), with the boundary between the respective blocks located, however, as in Fig. 3g or slightly eastward. Our results lead us to believe that the rifting process suggested by Polonia et al. (2017) between AlfeoEtna and Ionian faults in the Ionian basin should be taken in consideration in the future modeling of microplate geometry and kinematics. Concerning the doubts of D'Agostino et al. (2008) whether their assumption of a rigid Apulian-Ionian-Hyblean microplate is correct or not, our results in the Western Ionian showing evidence of a rifting process as proposed by Polonia et al. (2017) suggest that it is not.

We strongly feel that the usual assumption of rigid blocks or microplates in the physical modeling of geodynamic processes should be overcome and different crustal rheologies should be tested 
Solid Earth Discuss., https://doi.org/10.5194/se-2018-112

Manuscript under review for journal Solid Earth

Discussion started: 22 October 2018

(c) Author(s) 2018. CC BY 4.0 License.

when modeling tectonic deformation and microplate relative motions in the Central Mediterranean

452 region. For this purpose, we have recently started a research collaboration with the geophysical team of University of Milan for Finite Element Modeling of tectonic stress and strain distributions through high-resolution 3D thermo-rheological representation of lithosphere in the region of our interest. This line of research is grounded on methodological developments described in the papers by Splendore and Marotta (2013) and Marotta et al. (2015), among others.

\section{Conclusion}

Seismicity spatial patterns, earthquake focal mechanisms and seismogenic stress tensor orientations in and around Sicily, analyzed by use of seismometric data recorded in the last few decades, mark the dominant action of Africa-Eurasia NW-oriented plate convergence in this part of the Mediterranean region. Evidences of other tectonic factors acting together (or superimposed to) plate convergence are found in the Western Ionian sea where (i) residual slow subduction and SE-ward trench retreat reduce plate coupling in the Southern Calabria offshore and (ii) a rifting process with opening direction perpendicular to convergence at the southwestern edge of the subducting slab adds extensional stress to convergence-related compression in the offshore of Eastern Sicily. No seismic evidence of active rifting or microplate separation and divergence is detected in the Pelagian area of the Sicily Channel, where clear signatures of plate convergence are found, in agreement with findings of recent analyses of reflection profiles and structural data performed in the specific area (Cavallaro et al., 2016). In other words, our results do not support the hypothesis of

473 Sicily Channel rifting dynamics advanced by previous investigators using geodetic data under 474 microplate rigidity assumption (e.g. D’Agostino et al., 2008; Perouse et al., 2012). Also, our results 475 answer several open questions on tectonic strain in the Western Ionian left by Serpelloni et al. 476 (2007) (where strain locates between Hyblean and Apulia domains?), or by Palano et al. (2012) (is 
Solid Earth Discuss., https://doi.org/10.5194/se-2018-112

Manuscript under review for journal Solid Earth

Discussion started: 22 October 2018

(c) Author(s) 2018. CC BY 4.0 License.

Ionian rigidly connected with the Hyblean block or diverging from it and moving to northeast wrt to

478 Europe?) or, again, by D'Agostino et al. (2008) who admit that lack of GPS data in the Ionian

479 offshore does not allow decisive checking of their model assuming a rigid Apulia-Ionian-Hyblean microplate. Even taking into account the intrinsic limitations of our seismic datasets relative to (possibly short) time intervals of a few decades, but also considering their significance where GPS data are lacking or poor, the seismic data in our possess indicate that (i) strain "between Hyblean and Apulia domains" mainly locates around the southwestern edge of the Ionian subduction slab in the westernmost Ionian, (ii) the Ionian is not "rigidly connected with the Hyblean block" and (iii) the assumption of "a rigid Apulia-Ionian-Hyblean microplate" needs to be revised. Our results show that the assumption of rigid blocks or microplates made by previous investigators in their kinematic reconstructions should be overcome and different crustal rheologies should be tested when modeling tectonic deformation and microplate relative motions in this region. High-resolution 3D thermo-rheological representations of lithosphere in the frame of Finite Element Modeling of tectonic stress and strain distributions can, in our opinion, be an appropriate road towards geodynamic modeling of Southern Italy and the Central Mediterranean region. We are starting to work in this direction. 
Solid Earth Discuss., https://doi.org/10.5194/se-2018-112

Manuscript under review for journal Solid Earth

Discussion started: 22 October 2018

\section{Appendix A}

495 Table A1: Database of earthquake focal mechanisms of southern Italy and surroundings reported in

Fig. 5. ID is the order number. O.T., Lon, Lat and Depth are the GMT origin time, the longitude E

$\left(^{\circ}\right)$, the latitude $\mathrm{N}\left({ }^{\circ}\right)$ and the focal depth $(\mathrm{km})$ of the earthquake, respectively. Strike, dip, and rake

498

are the fault parameters in degrees of the focal solution. $M$ is the earthquake magnitude. Source is

the bibliographic source of the solution (Italian CMT= http://rcmt2.bo.ingv.it/Italydataset.html,

$\mathrm{TDMT}=$

501 http://cnt.rm.ingv.it/tdmt; the other sources are reported in the reference list at the end of the

502 article).

\begin{tabular}{|c|c|c|c|c|c|c|c|c|c|c|}
\hline Id & Data & O.T. & Lon & Lat & Depth & Strike & Dip & Rake & M & Source \\
\hline 1 & 19770605 & $13: 59: 23$ & 14.46 & 37.84 & 11.3 & 61 & 26 & -139 & 4.6 & Italian CMT \\
\hline 2 & 19770815 & $21: 10: 40$ & 16.98 & 38.85 & 40.0 & 307 & 38 & 120 & 5.2 & CMT \\
\hline 3 & 19780311 & $19: 20: 49$ & 16.03 & 38.10 & 15.0 & 270 & 41 & -72 & 5.2 & Italian CMT \\
\hline 4 & 19780415 & $23: 33: 47$ & 14.63 & 37.77 & 34.0 & 135 & 60 & -176 & 6.0 & Italian CMT \\
\hline 5 & 19790120 & $13: 49: 59$ & 12.86 & 38.67 & 9.0 & 72 & 29 & 53 & 5.2 & Italian CMT \\
\hline 6 & 19791208 & 00:06:33 & 11.49 & 37.95 & 15.0 & 235 & 45 & 67 & 5.3 & CMT \\
\hline 7 & 19800220 & $02: 34: 03$ & 16.21 & 39.30 & 12.0 & 14 & 43 & -78 & 4.8 & Italian CMT \\
\hline 8 & 19800309 & $12: 03: 40$ & 16.12 & 39.94 & 19.0 & 157 & 35 & -80 & 4.6 & Italian CMT \\
\hline 9 & 19800514 & 01:41:04 & 15.85 & 40.46 & 24.0 & 119 & 38 & -112 & 4.5 & Italian CMT \\
\hline 10 & 19800528 & 19:51:19 & 14.25 & 38.48 & 19.0 & 83 & 43 & 99 & 5.7 & Italian CMT \\
\hline 11 & 19800601 & $02: 32: 52$ & 14.33 & 38.39 & 10.0 & 65 & 39 & 91 & 4.9 & Italian CMT \\
\hline 12 & 19801123 & $18: 34: 54$ & 15.39 & 40.82 & 14.0 & 135 & 41 & -80 & 6.9 & Italian CMT \\
\hline 13 & 19801124 & 00:24:00 & 15.26 & 40.89 & 10.0 & 131 & 29 & -110 & 4.9 & Italian CMT \\
\hline 14 & 19801124 & 03:03:54 & 15.33 & 40.90 & 10.0 & 115 & 44 & -125 & 5.1 & Italian CMT \\
\hline 15 & 19801125 & 17:06:44 & 15.47 & 40.70 & 10.0 & 122 & 30 & -119 & 5.1 & Italian CMT \\
\hline 16 & 19801125 & $18: 28: 21$ & 15.36 & 40.15 & 15.0 & 129 & 26 & -65 & 5.4 & Italian CMT \\
\hline 17 & 19801203 & $23: 54: 24$ & 15.48 & 40.74 & 10.0 & 148 & 36 & -76 & 4.9 & Italian CMT \\
\hline 18 & 19810116 & $00: 37: 47$ & 15.23 & 40.13 & 15.0 & 115 & 30 & -93 & 5.2 & Italian CMT \\
\hline 19 & 19810607 & $13: 00: 57$ & 12.47 & 37.67 & 18.0 & 48 & 29 & 48 & 4.9 & Italian CMT \\
\hline 20 & 19810622 & 09:36:18 & 14.09 & 38.49 & 13.0 & 71 & 47 & 116 & 4.8 & Italian CMT \\
\hline 21 & 19811129 & 05:06:47 & 15.64 & 40.74 & 33.0 & 104 & 41 & -138 & 4.9 & Italian CMT \\
\hline 22 & 19820321 & 09:44:00 & 15.64 & 39.70 & 18.9 & 15 & 39 & -127 & 5.0 & Italian CMT \\
\hline 23 & 19820815 & $15: 09: 50$ & 15.36 & 40.81 & 10.0 & 158 & 48 & -45 & 4.8 & Italian CMT \\
\hline 24 & 19821116 & $23: 41: 29$ & 19.35 & 40.12 & 10.0 & 297 & 35 & 54 & 5.6 & CMT \\
\hline 25 & 19870128 & $05: 33: 22$ & 15.47 & 40.95 & 10.0 & 160 & 45 & -79 & 4.6 & Italian CMT \\
\hline 26 & 19870813 & $07: 22: 10$ & 15.06 & 37.90 & 35.9 & 352 & 42 & -10 & 4.8 & Italian CMT \\
\hline 27 & 19880108 & $13: 05: 46$ & 16.01 & 40.08 & 10.0 & 148 & 30 & -86 & 4.8 & Italian CMT \\
\hline 28 & 19880109 & 01:02:48 & 19.49 & 40.37 & 15.0 & 321 & 12 & 62 & 5.9 & CMT \\
\hline
\end{tabular}


Solid Earth Discuss., https://doi.org/10.5194/se-2018-112

Manuscript under review for journal Solid Earth

Discussion started: 22 October 2018

(c) Author(s) 2018. CC BY 4.0 License.

\begin{tabular}{|c|c|c|c|c|c|c|c|c|c|c|}
\hline 29 & 19880518 & 05:17:40 & 19.88 & 37.70 & 23.0 & 163 & 38 & 95 & 5.3 & CMT \\
\hline 30 & 19890103 & $16: 52: 24$ & 11.80 & 35.79 & 15.0 & 247 & 90 & 180 & 5.1 & CMT \\
\hline 31 & 19890824 & 02:13:12 & 19.72 & 37.05 & 15.0 & 356 & 38 & 131 & 5.2 & CMT \\
\hline 32 & 19900505 & $07: 21: 19$ & 15.58 & 40.24 & 26.0 & 184 & 73 & 13 & 5.8 & Italian CMT \\
\hline 33 & 19900505 & 07:38:12 & 15.81 & 40.75 & 15.0 & 282 & 83 & 173 & 5.0 & Italian CMT \\
\hline 34 & 19901029 & $08: 16: 14$ & 14.67 & 36.23 & 23.0 & 198 & 72 & -13 & 4.5 & Italian CMT \\
\hline 35 & 19901213 & $00: 24: 24$ & 14.90 & 37.25 & 15.0 & 274 & 64 & 174 & 5.6 & Italian CMT \\
\hline 36 & 19910526 & $12: 26: 00$ & 15.77 & 40.73 & 8.0 & 183 & 71 & -9 & 5.2 & Italian CMT \\
\hline 37 & 19920123 & 04:24:20 & 19.97 & 38.22 & 15.0 & 351 & 42 & 97 & 5.6 & CMT \\
\hline 38 & 19920406 & 13:08:34 & 14.61 & 37.83 & 21.0 & 100 & 37 & -97 & 4.7 & Italian CMT \\
\hline 39 & 19930626 & $17: 47: 54$ & 14.21 & 37.92 & 10.0 & 170 & 53 & 6 & 4.4 & Italian CMT \\
\hline 40 & 19940416 & 23:09:39 & 19.99 & 36.99 & 15.0 & 340 & 18 & 134 & 5.5 & CMT \\
\hline 41 & 19950529 & $06: 52: 27$ & 12.07 & 37.90 & 11.0 & 82 & 70 & -180 & 4.8 & Italian CMT \\
\hline 42 & 19960201 & 17:58:02 & 19.57 & 37.84 & 15.0 & 156 & 48 & 49 & 5.3 & CMT \\
\hline 43 & 19960403 & $13: 04: 34$ & 15.49 & 40.76 & 10.0 & 123 & 30 & -110 & 4.9 & Italian CMT \\
\hline 44 & 19961214 & $00: 18: 45$ & 13.84 & 37.81 & 40.0 & 123 & 23 & -43 & 4.7 & Italian CMT \\
\hline 45 & 19970112 & $12: 10: 51$ & 19.67 & 40.96 & 10.0 & 4 & 70 & -167 & 4.9 & RCMT \\
\hline 46 & 19970119 & $19: 42: 38$ & 19.67 & 40.82 & 10.0 & 2 & 65 & -177 & 4.7 & RCMT \\
\hline 47 & 19970325 & $00: 46: 14$ & 16.03 & 36.93 & 33.0 & 104 & 78 & 179 & 4.5 & Italian CMT \\
\hline 48 & 19971202 & $19: 22: 47$ & 19.40 & 36.68 & 15.0 & 206 & 49 & -20 & 5.2 & CMT \\
\hline 49 & 19980117 & $12: 32: 51$ & 12.90 & 38.40 & 10.0 & 58 & 29 & 71 & 4.8 & Italian CMT \\
\hline 50 & 19980620 & $02: 25: 47$ & 13.08 & 38.46 & 10.0 & 69 & 22 & 76 & 5.2 & Italian CMT \\
\hline 51 & 19980621 & 08:59:47 & 13.10 & 38.50 & 10.0 & 69 & 36 & 77 & 4.6 & Italian CMT \\
\hline 52 & 19980621 & $12: 59: 04$ & 12.67 & 38.43 & 10.0 & 88 & 38 & 102 & 4.6 & Italian CMT \\
\hline 53 & 19980909 & $11: 27: 59$ & 16.07 & 39.67 & 15.0 & 139 & 29 & -83 & 5.6 & Italian CMT \\
\hline 54 & 19980914 & $05: 24: 47$ & 13.60 & 38.46 & 10.0 & 72 & 30 & 80 & 5.0 & Italian CMT \\
\hline 55 & 19990214 & $11: 45: 54$ & 15.06 & 38.17 & 33.0 & 18 & 39 & -108 & 4.7 & Italian CMT \\
\hline 56 & 19991030 & 07:09:09 & 19.98 & 37.76 & 5.0 & 80 & 8 & -173 & 4.8 & RCMT \\
\hline 57 & 19991124 & 21:10:49 & 19.76 & 40.27 & 10.0 & 141 & 39 & 101 & 4.3 & RCMT \\
\hline 58 & 20000426 & $13: 37: 48$ & 10.10 & 40.98 & 10.0 & 179 & 39 & 83 & 4.8 & RCMT \\
\hline 59 & 20000428 & $17: 41: 02$ & 19.70 & 37.83 & 33.0 & 305 & 64 & -4 & 4.5 & RCMT \\
\hline 60 & 20000627 & 04:07:56 & 10.03 & 40.95 & 10.0 & 184 & 27 & 82 & 4.3 & RCMT \\
\hline 61 & 20010411 & $00: 10: 28$ & 16.12 & 40.43 & 16.6 & 130 & 20 & -90 & 3.0 & Orecchio\&al.(2014) \\
\hline 62 & 20010417 & $00: 42: 36$ & 19.47 & 40.64 & 10.0 & 343 & 43 & 97 & 4.2 & RCMT \\
\hline 63 & 20010422 & $13: 56: 36$ & 15.10 & 37.72 & 10.0 & 316 & 56 & 27 & 4.2 & Italian CMT \\
\hline 64 & 20010526 & 06:02:20 & 16.34 & 37.46 & 33.0 & 71 & 54 & 134 & 4.5 & Italian CMT \\
\hline 65 & 20010930 & $23: 44: 58$ & 16.04 & 40.22 & 12.6 & 30 & 70 & -80 & 2.7 & Orecchio\&al.(2014) \\
\hline 66 & 20011018 & $11: 02: 44$ & 16.61 & 39.10 & 10.0 & 332 & 44 & -88 & 4.3 & Italian CMT \\
\hline 67 & 20011125 & $19: 34: 20$ & 13.96 & 37.91 & 20.0 & 137 & 31 & -57 & 4.7 & Italian CMT \\
\hline 68 & 20020405 & $04: 52: 24$ & 14.74 & 38.48 & 10.0 & 90 & 41 & 108 & 4.4 & Italian CMT \\
\hline 69 & 20020417 & $06: 42: 54$ & 16.67 & 39.37 & 15.0 & 141 & 28 & 13 & 5.3 & Totaro\&al.(2016) \\
\hline 70 & 20020418 & $20: 56: 48$ & 15.58 & 40.69 & 10.0 & 340 & 49 & -52 & 4.4 & Italian CMT \\
\hline 71 & 20020624 & 01:20:43 & 10.29 & 36.03 & 15.0 & 28 & 48 & 128 & 5.2 & CMT \\
\hline 72 & 20020906 & $01: 21: 29$ & 13.57 & 38.42 & 15.0 & 26 & 50 & 40 & 5.9 & Italian CMT \\
\hline 73 & 20020906 & $01: 45: 30$ & 13.73 & 38.44 & 4.0 & 252 & 48 & 126 & 4.7 & Italian CMT \\
\hline 74 & 20020909 & 06:06:37 & 19.98 & 37.63 & 33.0 & 12 & 61 & -165 & 4.4 & RCMT \\
\hline
\end{tabular}


Solid Earth Discuss., https://doi.org/10.5194/se-2018-112

Manuscript under review for journal Solid Earth

Discussion started: 22 October 2018

(c) Author(s) 2018. CC BY 4.0 License.

\begin{tabular}{|c|c|c|c|c|c|c|c|c|c|c|}
\hline 75 & 20020910 & $02: 32: 51$ & 13.70 & 38.47 & 5.0 & 71 & 29 & 126 & 4.4 & Italian CMT \\
\hline 76 & 20020920 & 23:06:04 & 13.74 & 38.46 & 5.0 & 46 & 33 & 77 & 4.7 & Italian CMT \\
\hline 77 & 20020927 & $06: 10: 45$ & 13.66 & 38.41 & 15.0 & 35 & 24 & 65 & 5.2 & Totaro\&al.(2016) \\
\hline 78 & 20020928 & $02: 46: 46$ & 13.71 & 38.47 & 5.0 & 79 & 39 & 103 & 4.6 & Italian CMT \\
\hline 79 & 20021002 & $22: 57: 26$ & 13.72 & 38.46 & 5.0 & 33 & 41 & 59 & 4.9 & Italian CMT \\
\hline 80 & 20021027 & $02: 50: 26$ & 15.16 & 37.79 & 10.0 & 320 & 60 & 171 & 4.9 & Italian CMT \\
\hline 81 & 20021027 & 07:32:09 & 15.18 & 37.92 & 10.0 & 67 & 54 & 19 & 4.5 & Italian CMT \\
\hline 82 & 20021029 & 10:02:22 & 15.27 & 37.67 & 10.0 & 316 & 61 & -173 & 4.7 & Italian CMT \\
\hline 83 & 20021029 & $16: 39: 48$ & 15.56 & 37.69 & 10.0 & 207 & 54 & -28 & 4.2 & Italian CMT \\
\hline 84 & 20021209 & 09:35:06 & 19.97 & 37.87 & 15.0 & 255 & 28 & -20 & 5.2 & CMT \\
\hline 85 & 20030616 & $08: 27: 51$ & 19.73 & 37.69 & 10.0 & 321 & 31 & 43 & 4.7 & RCMT \\
\hline 86 & 20030707 & $15: 08: 12$ & 14.90 & 36.01 & 10.0 & 350 & 62 & 4 & 4.3 & Italian CMT \\
\hline 87 & 20041011 & 07:31:41 & 15.48 & 37.88 & 6.6 & 89 & 90 & -45 & 3.6 & D'Amico\&al.(2010) \\
\hline 88 & 20041022 & $21: 10: 13$ & 15.32 & 38.08 & 10.7 & 78 & 61 & -37 & 3.4 & D'Amico\&al.(2010) \\
\hline 89 & 20041218 & 09:12:48 & 10.15 & 40.89 & 10.0 & 144 & 49 & 51 & 4.6 & RCMT \\
\hline 90 & 20050131 & 01:05:35 & 19.97 & 37.37 & 12.0 & 346 & 16 & 120 & 5.7 & CMT \\
\hline 91 & 20050131 & $10: 44: 50$ & 16.86 & 39.66 & 30.0 & 23 & 79 & -41 & 4.1 & D'Amico\&al.(2011) \\
\hline 92 & 20050207 & $20: 05: 37$ & 10.91 & 36.10 & 10.0 & 67 & 44 & 128 & 4.8 & RCMT \\
\hline 93 & 20050207 & $20: 46: 26$ & 10.87 & 36.22 & 10.0 & 51 & 41 & 124 & 5.1 & RCMT \\
\hline 94 & 20050212 & $12: 13: 45$ & 19.70 & 39.92 & 0.0 & 187 & 42 & 53 & 4.2 & RCMT \\
\hline 95 & 20050419 & $22: 36: 23$ & 15.66 & 38.14 & 7.1 & 220 & 42 & -10 & 3.1 & D'Amico\&al.(2010) \\
\hline 96 & 20050423 & 19:10:48 & 15.82 & 38.43 & 13.6 & 120 & 50 & -64 & 2.8 & D'Amico\&al.(2010) \\
\hline 97 & 20050423 & 19:11:43 & 16.71 & 39.47 & 23.0 & 128 & 58 & 14 & 4.1 & D'Amico\&al.(2011) \\
\hline 98 & 20050602 & 03:05:51 & 15.31 & 39.59 & 7.0 & 278 & 73 & -172 & 3.7 & Li\&al.(2007) \\
\hline 99 & 20050721 & $15: 41: 43$ & 14.85 & 39.40 & 7.0 & 184 & 68 & 41 & 3.8 & Li\&al.(2007) \\
\hline 100 & 20050818 & $22: 02: 27$ & 15.12 & 37.80 & 6.7 & 82 & 50 & -18 & 3.1 & D'Amico\&al.(2010) \\
\hline 101 & 20050907 & $12: 40: 33$ & 16.32 & 38.71 & 16.0 & 80 & 90 & -42 & 3.6 & D'Amico\&al.(2011) \\
\hline 102 & 20050927 & 22:33:09 & 17.10 & 38.62 & 29.0 & 38 & 79 & 141 & 3.9 & Li\&al.(2007) \\
\hline 103 & 20051030 & 19:09:47 & 15.93 & 38.53 & 22.0 & 241 & 66 & -84 & 3.4 & Li\&al.(2007) \\
\hline 104 & 20051118 & $18: 35: 25$ & 17.07 & 39.17 & 23.0 & 120 & 34 & 3 & 3.6 & D'Amico\&al.(2011) \\
\hline 105 & 20051121 & $10: 57: 41$ & 14.16 & 37.61 & 61.0 & 102 & 79 & 179 & 4.6 & RCMT \\
\hline 106 & 20051203 & 08:33:02 & 17.00 & 39.20 & 15.0 & 290 & 64 & -18 & 3.8 & Presti\&al.(2013) \\
\hline 107 & 20060107 & 22:08:44 & 17.21 & 39.27 & 16.0 & 174 & 69 & 61 & 3.2 & Orecchio\&al.(2014) \\
\hline 108 & 20060117 & 03:33:58 & 17.13 & 39.20 & 34.0 & 146 & 62 & -21 & 3.7 & Orecchio\&al.(2014) \\
\hline 109 & 20060227 & 04:34:01 & 15.20 & 38.15 & 9.0 & 62 & 50 & -71 & 4.1 & D'Amico\&al.(2010) \\
\hline 110 & 20060227 & 09:11:59 & 15.18 & 38.14 & 10.5 & 39 & 48 & -90 & 3.1 & D'Amico\&al.(2010) \\
\hline 111 & 20060227 & 14:16:06 & 15.18 & 38.14 & 9.1 & 76 & 48 & -58 & 3.1 & D'Amico\&al.(2010) \\
\hline 112 & 20060329 & $20: 20: 00$ & 13.89 & 37.73 & 10.0 & 338 & 80 & -42 & 3.9 & TDMT \\
\hline 113 & 20060417 & 02:44:06 & 17.14 & 39.57 & 10.0 & 114 & 74 & -3 & 4.4 & D'Amico\&al.(2011) \\
\hline 114 & 20060423 & $14: 42: 38$ & 15.02 & 37.04 & 24.0 & 100 & 88 & 147 & 3.9 & TDMT \\
\hline 115 & 20060510 & $00: 44: 33$ & 19.31 & 40.23 & 5.0 & 292 & 72 & 10 & 4.5 & RCMT \\
\hline 116 & 20060510 & 21:33:06 & 19.78 & 40.06 & 18.0 & 289 & 59 & 7 & 4.3 & RCMT \\
\hline 117 & 20060520 & 07:05:56 & 14.95 & 37.65 & 12.0 & 280 & 75 & 47 & 3.7 & TDMT \\
\hline 118 & 20060525 & $23: 14: 41$ & 19.91 & 36.55 & 23.0 & 346 & 23 & 129 & 5.2 & CMT \\
\hline 119 & 20060530 & $11: 30: 40$ & 16.52 & 37.63 & 46.0 & 347 & 85 & 0 & 4.5 & RCMT \\
\hline 120 & 20060613 & $14: 15: 38$ & 19.96 & 40.27 & 10.0 & 283 & 67 & 25 & 4.7 & RCMT \\
\hline
\end{tabular}


Solid Earth Discuss., https://doi.org/10.5194/se-2018-112

Manuscript under review for journal Solid Earth

Discussion started: 22 October 2018

(c) Author(s) 2018. CC BY 4.0 License.

\begin{tabular}{|c|c|c|c|c|c|c|c|c|c|c|}
\hline 121 & 20060619 & $20: 55: 35$ & 14.89 & 37.83 & 16.0 & 350 & 28 & 11 & 3.8 & Neri\&al.(2014) \\
\hline 122 & 20060619 & $21: 20: 13$ & 14.88 & 37.83 & 18.0 & 354 & 32 & 2 & 3.1 & Totaro\&al.(2016) \\
\hline 123 & 20060619 & $21: 27: 12$ & 14.87 & 37.82 & 20.0 & 0 & 37 & 9 & 3.1 & Totaro\&al.(2016) \\
\hline 124 & 20060620 & $13: 16: 36$ & 14.86 & 37.83 & 18.0 & 0 & 26 & 22 & 3.3 & Totaro\&al.(2016) \\
\hline 125 & 20060621 & $07: 17: 50$ & 14.83 & 37.83 & 18.0 & 354 & 23 & 11 & 3.3 & Totaro\&al.(2016) \\
\hline 126 & 20060622 & $19: 34: 58$ & 16.60 & 39.73 & 15.0 & 110 & 33 & -33 & 4.4 & D'Amico\&al.(2011) \\
\hline 127 & 20060702 & 17:52:00 & 15.10 & 38.13 & 10.0 & 70 & 59 & -49 & 2.6 & D'Amico\&al.(2010) \\
\hline 128 & 20060718 & 07:42:40 & 15.17 & 38.12 & 9.1 & 90 & 41 & -48 & 3.1 & D'Amico\&al.(2010) \\
\hline 129 & 20060730 & 09:53:36 & 16.31 & 37.99 & 6.0 & 292 & 64 & -7 & 2.7 & Orecchio\&al.(2014) \\
\hline 130 & 20060805 & $20: 47: 19$ & 14.73 & 38.55 & 10.0 & 40 & 30 & 39 & 3.3 & Totaro\&al.(2016) \\
\hline 131 & 20060806 & $07: 49: 49$ & 19.53 & 40.05 & 16.0 & 20 & 44 & 146 & 4.8 & CMT \\
\hline 132 & 20060808 & $21: 20: 12$ & 19.60 & 40.04 & 20.0 & 13 & 38 & 138 & 4.8 & CMT \\
\hline 133 & 20060809 & 02:10:01 & 19.59 & 40.11 & 19.0 & 312 & 69 & 16 & 4.2 & RCMT \\
\hline 134 & 20060819 & $16: 29: 11$ & 14.43 & 38.58 & 26.0 & 229 & 78 & 28 & 3.3 & Totaro\&al.(2016) \\
\hline 135 & 20060830 & $22: 45: 03$ & 15.72 & 37.32 & 30.0 & 190 & 64 & -23 & 3.1 & Orecchio\&al.(2014) \\
\hline 136 & 20060901 & 21:50:41 & 19.87 & 40.05 & 50.0 & 129 & 64 & 63 & 4.4 & present work \\
\hline 137 & 20060907 & $15: 31: 43$ & 16.19 & 40.57 & 34.0 & 178 & 55 & 35 & 4.1 & Italian CMT \\
\hline 138 & 20060909 & $15: 45: 23$ & 14.23 & 38.70 & 8.0 & 222 & 68 & 13 & 3.3 & Totaro\&al.(2016) \\
\hline 139 & 20061006 & $21: 16: 23$ & 15.57 & 38.10 & 9.6 & 18 & 52 & -90 & 3.2 & D'Amico\&al.(2010) \\
\hline 140 & 20061022 & 05:13:10 & 16.70 & 39.05 & 10.0 & 312 & 38 & -30 & 3.0 & Orecchio\&al.(2014) \\
\hline 141 & 20061104 & 05:59:22 & 15.01 & 38.03 & 10.6 & 59 & 49 & -36 & 3.0 & D'Amico\&al.(2010) \\
\hline 142 & 20061107 & $11: 13: 36$ & 18.26 & 35.91 & 35.0 & 201 & 30 & 93 & 4.3 & RCMT \\
\hline 143 & 20061118 & 00:01:56 & 17.23 & 39.06 & 24.0 & 113 & 46 & -51 & 3.0 & Orecchio\&al.(2014) \\
\hline 144 & 20061123 & $13: 31: 56$ & 12.94 & 35.97 & 10.0 & 357 & 70 & -2 & 4.8 & RCMT \\
\hline 145 & 20061124 & 04:37:40 & 15.76 & 36.26 & 11.0 & 188 & 82 & 0 & 4.4 & Italian CMT \\
\hline 146 & 20061219 & 14:58:06 & 14.91 & 37.78 & 23.0 & 18 & 16 & -40 & 4.2 & Italian CMT \\
\hline 147 & 20061220 & 11:38:08 & 14.26 & 38.54 & 6.0 & 201 & 64 & 13 & 3.6 & Neri\&al.(2014) \\
\hline 148 & 20061226 & 00:49:00 & 16.17 & 39.22 & 2.0 & 223 & 38 & -12 & 3.1 & Orecchio\&al.(2014) \\
\hline 149 & 20070130 & 22:18:07 & 16.14 & 39.91 & 8.0 & 84 & 90 & 19 & 3.6 & Orecchio\&al.(2014) \\
\hline 150 & 20070202 & 06:51:01 & 16.35 & 39.55 & 12.0 & 31 & 48 & -61 & 3.2 & Totaro\&al.(2013) \\
\hline 151 & 20070326 & $13: 55: 26$ & 16.96 & 39.28 & 20.0 & 301 & 61 & 8 & 3.7 & Totaro\&al.(2016) \\
\hline 152 & 20070410 & $19: 17: 23$ & 12.91 & 36.93 & 22.0 & 100 & 75 & 164 & 4.1 & TDMT \\
\hline 153 & 20070421 & $19: 41: 27$ & 13.43 & 38.57 & 12.0 & 250 & 52 & 10 & 3.9 & Neri\&al.(2014) \\
\hline 154 & 20070426 & $00: 49: 36$ & 16.37 & 39.54 & 16.0 & 290 & 8 & 20 & 3.8 & Orecchio\&al.(2014) \\
\hline 155 & 20070503 & $18: 43: 56$ & 17.63 & 39.02 & 18.0 & 92 & 25 & -31 & 3.5 & Orecchio\&al.(2014) \\
\hline 156 & 20070517 & $05: 48: 13$ & 14.69 & 38.57 & 8.0 & 22 & 50 & 8 & 3.5 & Presti\&al.(2013) \\
\hline 157 & 20070525 & 09:39:45 & 16.83 & 39.66 & 12.0 & 91 & 29 & -48 & 4.2 & D'Amico\&al.(2011) \\
\hline 158 & 20070609 & $05: 56: 38$ & 16.62 & 39.18 & 18.0 & 71 & 49 & -59 & 3.1 & Orecchio\&al.(2014) \\
\hline 159 & 20070615 & 22:56:01 & 15.29 & 36.97 & 18.0 & 12 & 87 & 20 & 3.6 & TDMT \\
\hline 160 & 20070617 & $12: 11: 58$ & 15.79 & 38.37 & 10.0 & 262 & 38 & -43 & 2.9 & D'Amico\&al.(2010) \\
\hline 161 & 20070706 & $23: 28: 43$ & 17.25 & 39.18 & 28.0 & 118 & 38 & -35 & 3.5 & Orecchio\&al.(2014) \\
\hline 162 & 20070714 & 18:13:03 & 14.75 & 38.63 & 4.0 & 30 & 31 & 38 & 3.1 & Presti\&al.(2013) \\
\hline 163 & 20070731 & 06:53:16 & 14.74 & 37.47 & 32.0 & 142 & 78 & -21 & 3.4 & Totaro\&al.(2016) \\
\hline 164 & 20070801 & 00:07:54 & 17.18 & 39.00 & 18.0 & 80 & 67 & -45 & 4.1 & D'Amico\&al.(2011) \\
\hline 165 & 20070818 & 14:04:07 & 15.17 & 38.22 & 12.0 & 44 & 50 & -23 & 3.9 & D'Amico\&al.(2010) \\
\hline 166 & 20070818 & $14: 21: 11$ & 15.12 & 38.19 & 10.0 & 26 & 69 & 18 & 3.4 & D'Amico\&al.(2010) \\
\hline
\end{tabular}


Solid Earth Discuss., https://doi.org/10.5194/se-2018-112

Manuscript under review for journal Solid Earth

Discussion started: 22 October 2018

(c) Author(s) 2018. CC BY 4.0 License.

\begin{tabular}{|c|c|c|c|c|c|c|c|c|c|c|}
\hline 167 & 20070905 & $21: 24: 13$ & 14.84 & 38.56 & 6.0 & 10 & 54 & -2 & 3.3 & Totaro\&al.(2016) \\
\hline 168 & 20070913 & $15: 19: 52$ & 15.16 & 38.25 & 8.0 & 246 & 82 & -60 & 2.9 & Totaro\&al.(2016) \\
\hline 169 & 20070923 & 07:12:46 & 14.79 & 38.59 & 8.0 & 27 & 60 & 28 & 3.6 & Presti\&al.(2013) \\
\hline 170 & 20070930 & $15: 41: 20$ & 14.80 & 38.59 & 6.0 & 70 & 73 & 16 & 3.1 & Presti\&al.(2013) \\
\hline 171 & 20071213 & $23: 38: 24$ & 16.61 & 38.93 & 30.0 & 98 & 9 & -17 & 3.2 & Orecchio\&al.(2014) \\
\hline 172 & 20071214 & $00: 42: 55$ & 16.62 & 38.93 & 26.0 & 331 & 70 & -60 & 3.0 & Orecchio\&al.(2014) \\
\hline 173 & 20071217 & 09:44:39 & 16.36 & 39.39 & 40.0 & 162 & 90 & -71 & 3.5 & Orecchio\&al.(2014) \\
\hline 174 & 20071220 & $03: 25: 32$ & 16.19 & 39.36 & 2.0 & 210 & 66 & -71 & 3.5 & Orecchio\&al.(2014) \\
\hline 175 & 20080115 & 02:38:31 & 16.33 & 39.81 & 18.0 & 327 & 80 & 39 & 3.2 & Orecchio\&al.(2014) \\
\hline 176 & 20080118 & 13:01:00 & 16.53 & 39.14 & 12.0 & 57 & 78 & -67 & 3.9 & TDMT \\
\hline 177 & 20080209 & $07: 46: 36$ & 15.56 & 37.84 & 6.9 & 40 & 90 & -10 & 3.0 & D'Amico\&al.(2010) \\
\hline 178 & 20080221 & 05:00:09 & 17.97 & 37.82 & 30.0 & 333 & 27 & 134 & 4.7 & Italian CMT \\
\hline 179 & 20080305 & 04:08:21 & 19.67 & 40.22 & 0.0 & 173 & 47 & 152 & 4.1 & RCMT \\
\hline 180 & 20080310 & $10: 33: 27$ & 16.85 & 39.66 & 20.0 & 121 & 39 & -7 & 3.5 & Presti\&al.(2013) \\
\hline 181 & 20080408 & $17: 20: 01$ & 16.66 & 39.16 & 10.0 & 235 & 49 & -35 & 4.4 & Italian CMT \\
\hline 182 & 20080413 & 10:10:02 & 16.52 & 39.16 & 14.0 & 205 & 69 & -90 & 3.6 & D'Amico\&al.(2010) \\
\hline 183 & 20080413 & $13: 06: 57$ & 15.70 & 38.25 & 14.3 & 6 & 47 & -36 & 2.8 & Orecchio\&al.(2014) \\
\hline 184 & 20080414 & $18: 44: 34$ & 16.52 & 39.15 & 12.0 & 48 & 41 & -62 & 3.1 & Orecchio\&al.(2014) \\
\hline 185 & 20080419 & 21:41:11 & 17.47 & 39.13 & 16.0 & 107 & 42 & -39 & 3.6 & Presti\&al.(2013) \\
\hline 186 & 20080426 & 22:23:06 & 16.53 & 39.14 & 18.0 & 256 & 60 & -31 & 3.2 & Orecchio\&al.(2014) \\
\hline 187 & 20080501 & 21:05:49 & 15.07 & 37.80 & 2.0 & 97 & 76 & -2 & 2.8 & D'Amico\&al.(2010) \\
\hline 188 & 20080513 & $21: 28: 30$ & 15.06 & 37.80 & 12.0 & 76 & 46 & -20 & 3.5 & D'Amico\&al.(2010) \\
\hline 189 & 20080702 & $17: 43: 33$ & 16.23 & 38.97 & 30.0 & 266 & 69 & -30 & 3.2 & Orecchio\&al.(2014) \\
\hline 190 & 20080703 & $20: 56: 52$ & 13.71 & 38.45 & 24.2 & 182 & 68 & 27 & 3.3 & TDMT \\
\hline 191 & 20080705 & $17: 04: 36$ & 15.87 & 38.20 & 2.0 & 311 & 59 & 2 & 2.6 & D'Amico\&al.(2010) \\
\hline 192 & 20080709 & 23:08:27 & 16.23 & 38.97 & 24.0 & 268 & 76 & -32 & 3.3 & Orecchio\&al.(2014) \\
\hline 193 & 20080710 & 01:45:45 & 16.24 & 38.97 & 12.0 & 76 & 72 & -40 & 3.0 & Orecchio\&al.(2014) \\
\hline 194 & 20080710 & $12: 50: 20$ & 16.24 & 38.96 & 14.0 & 71 & 75 & -39 & 3.3 & Orecchio\&al.(2014) \\
\hline 195 & 20080711 & 07:15:00 & 16.24 & 38.96 & 16.0 & 50 & 52 & -29 & 3.0 & Orecchio\&al.(2014) \\
\hline 196 & 20080711 & 07:20:21 & 16.25 & 38.96 & 12.0 & 78 & 80 & -58 & 2.9 & Orecchio\&al.(2014) \\
\hline 197 & 20080813 & $13: 39: 30$ & 16.42 & 37.48 & 34.0 & 181 & 71 & 11 & 3.2 & Orecchio\&al.(2014) \\
\hline 198 & 20080901 & $14: 45: 40$ & 15.06 & 37.97 & 8.1 & 70 & 31 & -80 & 3.1 & D'Amico\&al.(2010) \\
\hline 199 & 20080902 & 09:16:45 & 15.06 & 37.99 & 10.3 & 279 & 64 & -44 & 3.3 & D'Amico\&al.(2010) \\
\hline 200 & 20080902 & $21: 57: 20$ & 15.69 & 38.25 & 34.0 & 351 & 72 & -65 & 3.1 & Orecchio\&al.(2014) \\
\hline 201 & 20080910 & 11:30:48 & 17.13 & 39.18 & 34.0 & 81 & 69 & -90 & 4.6 & Orecchio\&al.(2014) \\
\hline 202 & 20080912 & 20:12:11 & 17.37 & 39.17 & 34.0 & 332 & 85 & -2 & 3.6 & Orecchio\&al.(2014) \\
\hline 203 & 20080927 & $08: 28: 27$ & 17.21 & 39.18 & 30.0 & 123 & 71 & -8 & 4.0 & Totaro \& al. (2016) \\
\hline 204 & 20081024 & $16: 55: 37$ & 16.44 & 38.61 & 30.0 & 0 & 60 & 70 & 3.3 & Orecchio\&al.(2014) \\
\hline 205 & 20081024 & $18: 47: 54$ & 16.47 & 38.59 & 28.0 & 323 & 38 & -24 & 3.4 & Orecchio\&al.(2014) \\
\hline 206 & 20081027 & $10: 55: 55$ & 15.13 & 38.11 & 2.0 & 50 & 28 & -71 & 3.5 & D'Amico\&al.(2010) \\
\hline 207 & 20081102 & $06: 46: 44$ & 16.49 & 37.64 & 40.0 & 141 & 67 & -79 & 3.6 & Orecchio\&al.(2014) \\
\hline 208 & 20081107 & $15: 00: 59$ & 16.46 & 39.15 & 14.0 & 139 & 72 & -65 & 3.3 & Orecchio\&al.(2014) \\
\hline 209 & 20081120 & 14:09:21 & 17.49 & 39.14 & 15.0 & 166 & 82 & -2 & 4.5 & Italian CMT \\
\hline 210 & 20081128 & 08:04:47 & 17.02 & 39.89 & 34.0 & 97 & 50 & 21 & 3.6 & Orecchio\&al.(2014) \\
\hline 211 & 20081128 & 23:39:21 & 13.69 & 37.54 & 35.0 & 337 & 74 & 9 & 4.4 & Italian CMT \\
\hline 212 & 20081209 & $12: 55: 27$ & 17.20 & 39.04 & 24.0 & 104 & 21 & -31 & 3.6 & Orecchio\&al.(2014) \\
\hline
\end{tabular}


Solid Earth Discuss., https://doi.org/10.5194/se-2018-112

Manuscript under review for journal Solid Earth

Discussion started: 22 October 2018

(c) Author(s) 2018. CC BY 4.0 License.

\begin{tabular}{|c|c|c|c|c|c|c|c|c|c|c|}
\hline 213 & 20081225 & $18: 55: 58$ & 15.96 & 40.34 & 6.0 & 100 & 59 & -23 & 2.6 & Orecchio\&al.(2014) \\
\hline 214 & 20090205 & $14: 50: 14$ & 16.03 & 37.39 & 28.0 & 167 & 78 & 18 & 3.3 & Orecchio\&al.(2014) \\
\hline 215 & 20090316 & 00:28:06 & 15.96 & 37.67 & 28.0 & 34 & 60 & -24 & 3.0 & Orecchio\&al.(2014) \\
\hline 216 & 20090319 & $08: 27: 54$ & 12.72 & 36.52 & 28.0 & 255 & 48 & -180 & 4.4 & Italian CMT \\
\hline 217 & 20090325 & $12: 23: 25$ & 19.63 & 40.34 & 10.0 & 3 & 35 & 90 & 4.3 & RCMT \\
\hline 218 & 20090407 & $20: 24: 54$ & 16.81 & 39.19 & 14.0 & 161 & 70 & -33 & 3.2 & Orecchio\&al.(2014) \\
\hline 219 & 20090413 & $11: 39: 58$ & 16.39 & 39.53 & 8.0 & 260 & 40 & -7 & 3.3 & Totaro\&al.(2013) \\
\hline 220 & 20090427 & 09:42:16 & 15.08 & 38.07 & 30.0 & 69 & 78 & -19 & 3.6 & Presti\&al.(2013) \\
\hline 221 & 20090701 & $17: 58: 54$ & 15.01 & 38.34 & 2.0 & 40 & 90 & 19 & 3.1 & Presti\&al.(2013) \\
\hline 222 & 20090727 & $22: 15: 14$ & 15.69 & 37.12 & 30.0 & 353 & 48 & -13 & 3.2 & Orecchio\&al.(2014) \\
\hline 223 & 20090804 & $16: 17: 16$ & 15.71 & 37.12 & 18.0 & 22 & 73 & -13 & 3.6 & Orecchio\&al.(2014) \\
\hline 224 & 20090829 & $06: 55: 17$ & 15.47 & 37.92 & 8.0 & 56 & 80 & -47 & 2.9 & Orecchio\&al.(2014) \\
\hline 225 & 20090907 & $21: 26: 31$ & 13.98 & 38.73 & 18.0 & 63 & 39 & 65 & 4.8 & Totaro\&al.(2016) \\
\hline 226 & 20090917 & 22:53:00 & 19.96 & 39.95 & 10.0 & 307 & 55 & 44 & 4.5 & RCMT \\
\hline 227 & 20091012 & 20:07:49 & 15.96 & 37.23 & 30.0 & 204 & 82 & 12 & 3.4 & Orecchio\&al.(2014) \\
\hline 228 & 20091108 & $06: 51: 16$ & 14.55 & 37.83 & 15.0 & 310 & 21 & -54 & 4.5 & RCMT \\
\hline 229 & 20091125 & 06:20:07 & 16.45 & 38.05 & 16.0 & 341 & 62 & -43 & 3.2 & Orecchio\&al.(2014) \\
\hline 230 & 20091215 & 11:49:07 & 15.57 & 38.96 & 24.0 & 195 & 61 & -54 & 3.7 & Orecchio\&al.(2014) \\
\hline 231 & 20091219 & 09:01:19 & 15.09 & 37.76 & 40.0 & 112 & 44 & 176 & 4.4 & Italian CMT \\
\hline 232 & 20100101 & $22: 01: 13$ & 16.29 & 39.20 & 36.0 & 267 & 58 & -60 & 3.8 & Orecchio\&al.(2014) \\
\hline 233 & 20100208 & 07:23:58 & 16.77 & 39.50 & 34.0 & 94 & 73 & -31 & 3.6 & Presti\&al.(2013) \\
\hline 234 & 20100317 & 11:01:11 & 14.73 & 38.57 & 8.0 & 78 & 56 & 81 & 3.3 & Presti\&al.(2013) \\
\hline 235 & 20100325 & $17: 30: 18$ & 15.86 & 40.03 & 2.0 & 0 & 51 & -67 & 3.2 & Orecchio\&al.(2014) \\
\hline 236 & 20100402 & 20:04:47 & 15.11 & 37.76 & 2.0 & 274 & 55 & 10 & 4.2 & Italian CMT \\
\hline 237 & 20100404 & $15: 40: 28$ & 16.82 & 39.35 & 22.0 & 314 & 76 & -18 & 3.3 & Presti\&al.(2013) \\
\hline 238 & 20100413 & $12: 12: 14$ & 17.15 & 39.35 & 18.0 & 128 & 29 & -26 & 3.5 & Presti\&al.(2013) \\
\hline 239 & 20100415 & $20: 05: 47$ & 17.22 & 39.35 & 18.0 & 137 & 39 & -15 & 3.6 & Presti\&al.(2013) \\
\hline 240 & 20100511 & $10: 28: 47$ & 16.22 & 39.75 & 6.0 & 152 & 56 & -90 & 2.8 & Orecchio\&al.(2014) \\
\hline 241 & 20100511 & 18:09:43 & 17.47 & 39.31 & 22.0 & 126 & 40 & -28 & 3.8 & Orecchio\&al.(2014) \\
\hline 242 & 20100606 & $16: 49: 53$ & 15.11 & 38.27 & 10.0 & 237 & 82 & -34 & 3.5 & Presti\&al.(2013) \\
\hline 243 & 20100616 & $22: 39: 41$ & 16.14 & 38.83 & 15.0 & 109 & 50 & -38 & 4.1 & Italian CMT \\
\hline 244 & 20100801 & $21: 31: 53$ & 14.46 & 38.61 & 4.0 & 37 & 60 & 78 & 3.1 & Presti\&al.(2013) \\
\hline 245 & 20100816 & $12: 54: 46$ & 14.92 & 38.42 & 10.0 & 218 & 66 & 42 & 4.5 & Presti\&al.(2013) \\
\hline 246 & 20100822 & 10:23:05 & 19.95 & 37.27 & 17.0 & 325 & 16 & 99 & 5.5 & CMT \\
\hline 247 & 20100910 & $19: 19: 48$ & 16.21 & 38.54 & 26.0 & 198 & 53 & -60 & 3.3 & Orecchio\&al.(2014) \\
\hline 248 & 20100910 & 21:39:20 & 15.82 & 38.20 & 28.0 & 204 & 69 & -70 & 3.2 & Orecchio\&al.(2014) \\
\hline 249 & 20101008 & $17: 26: 58$ & 16.33 & 36.91 & 38.0 & 190 & 79 & 17 & 3.6 & Orecchio\&al.(2014) \\
\hline 250 & 20101014 & $14: 18: 28$ & 16.69 & 38.84 & 28.0 & 60 & 60 & 31 & 3.2 & Orecchio\&al.(2014) \\
\hline 251 & 20101015 & $05: 21: 20$ & 16.66 & 38.87 & 15.0 & 287 & 62 & 173 & 4.4 & Italian CMT \\
\hline 252 & 20101109 & 08:43:20 & 15.93 & 40.05 & 10.0 & 329 & 61 & -57 & 3.5 & Orecchio\&al.(2014) \\
\hline 253 & 20101127 & 08:45:49 & 15.64 & 38.08 & 38.0 & 332 & 22 & -12 & 3.7 & Orecchio\&al.(2014) \\
\hline 254 & 20110325 & $16: 18: 12$ & 16.94 & 38.87 & 6.0 & 87 & 70 & -53 & 3.3 & Orecchio\&al.(2014) \\
\hline 255 & 20110325 & $18: 31: 31$ & 16.96 & 38.87 & 6.0 & 281 & 53 & -19 & 3.6 & Orecchio\&al.(2014) \\
\hline 256 & 20110424 & $13: 02: 12$ & 14.88 & 35.82 & 20.3 & 28 & 34 & -76 & 4.2 & RCMT \\
\hline 257 & 20110426 & 21:02:30 & 15.16 & 38.15 & 2.0 & 33 & 40 & -90 & 3.2 & Totaro\&al.(2016) \\
\hline 258 & 20110503 & $22: 24: 52$ & 16.68 & 37.78 & 36.0 & 323 & 49 & -41 & 3.6 & Orecchio\&al.(2014) \\
\hline
\end{tabular}


Solid Earth Discuss., https://doi.org/10.5194/se-2018-112

Manuscript under review for journal Solid Earth

Discussion started: 22 October 2018

Solid Earth

(c) Author(s) 2018. CC BY 4.0 License.

\begin{tabular}{|c|c|c|c|c|c|c|c|c|c|c|}
\hline 259 & 20110506 & $15: 12: 35$ & 14.96 & 37.78 & 22.2 & 13 & 57 & 15 & 4.0 & Italian CMT \\
\hline 260 & 20110609 & $16: 16: 36$ & 19.75 & 40.69 & 10.0 & 171 & 78 & -170 & 4.4 & RCMT \\
\hline 261 & 20110623 & $22: 02: 47$ & 14.78 & 38.06 & 10.0 & 315 & 90 & -1 & 4.7 & Neri\&al.(2014) \\
\hline 262 & 20110624 & 09:00:08 & 16.61 & 39.61 & 22.0 & 330 & 21 & -20 & 3.1 & Totaro\&al.(2013) \\
\hline 263 & 20110627 & $05: 23: 41$ & 14.74 & 38.02 & 8.0 & 313 & 63 & -2 & 3.2 & Totaro\&al.(2016) \\
\hline 264 & 20110627 & $22: 13: 45$ & 14.74 & 38.04 & 10.0 & 299 & 44 & -31 & 3.4 & Totaro\&al.(2016) \\
\hline 265 & 20110629 & 09:04:17 & 14.73 & 38.05 & 8.0 & 305 & 90 & 2 & 3.2 & Totaro\&al.(2016) \\
\hline 266 & 20110629 & 19:15:15 & 14.74 & 38.06 & 10.0 & 139 & 81 & -10 & 3.5 & Totaro\&al.(2016) \\
\hline 267 & 20110706 & 09:08:39 & 14.78 & 38.05 & 10.0 & 124 & 42 & -41 & 3.7 & Neri\&al.(2014) \\
\hline 268 & 20110707 & 01:01:15 & 14.79 & 38.04 & 10.0 & 315 & 90 & 10 & 3.3 & Totaro\&al.(2016) \\
\hline 269 & 20110727 & 04:03:14 & 14.77 & 38.06 & 8.0 & 113 & 46 & -61 & 3.2 & Totaro\&al.(2016) \\
\hline 270 & 20110817 & 01:20:32 & 14.47 & 38.55 & 6.0 & 209 & 70 & 38 & 3.0 & Totaro\&al.(2016) \\
\hline 271 & 20110831 & $16: 33: 20$ & 14.70 & 37.11 & 2.0 & 7 & 80 & 1 & 3.1 & Totaro\&al.(2016) \\
\hline 272 & 20111103 & $14: 37: 10$ & 14.58 & 38.43 & 10.0 & 8 & 90 & 22 & 3.5 & Totaro\&al.(2016) \\
\hline 273 & 20111109 & 17:00:48 & 16.02 & 39.91 & 9.0 & 10 & 50 & -51 & 2.7 & Totaro\&al.(2015) \\
\hline 274 & 20111115 & 04:59:00 & 14.67 & 38.27 & 10.0 & 18 & 74 & 9 & 4.1 & Neri\&al.(2014) \\
\hline 275 & 20111119 & 10:19:16 & 14.35 & 37.81 & 14.0 & 121 & 70 & -25 & 3.4 & Totaro\&al.(2016) \\
\hline 276 & 20111123 & $14: 12: 34$ & 16.01 & 39.92 & 9.0 & 7 & 40 & -48 & 3.5 & Totaro\&al.(2015) \\
\hline 277 & 20111201 & 14:01:20 & 16.01 & 39.93 & 9.8 & 7 & 48 & -52 & 3.3 & Totaro\&al.(2015) \\
\hline 278 & 20111202 & $21: 25: 38$ & 16.01 & 39.92 & 9.8 & 156 & 49 & -90 & 3.2 & Totaro\&al.(2015) \\
\hline 279 & 20111214 & $17: 59: 49$ & 16.20 & 39.38 & 6.0 & 178 & 39 & -43 & 3.1 & Orecchio\&al.(2014) \\
\hline 280 & 20111217 & $23: 20: 15$ & 16.18 & 39.37 & 26.0 & 345 & 62 & -79 & 3.6 & Orecchio\&al.(2014) \\
\hline 281 & 20111218 & 15:01:06 & 12.68 & 36.10 & 12.0 & 183 & 85 & 2 & 4.7 & CMT \\
\hline 282 & 20111224 & $20: 17: 50$ & 16.02 & 39.92 & 9.1 & 348 & 44 & -90 & 3.2 & Totaro\&al.(2015) \\
\hline 283 & 20111227 & 01:07:45 & 16.92 & 39.58 & 20.0 & 121 & 28 & -26 & 3.6 & Totaro\&al.(2016) \\
\hline 284 & 20120103 & $23: 47: 41$ & 16.84 & 39.64 & 16.0 & 156 & 29 & -29 & 3.1 & Orecchio\&al.(2014) \\
\hline 285 & 20120129 & $11: 14: 50$ & 14.27 & 37.88 & 10.0 & 37 & 61 & -23 & 3.0 & Totaro\&al.(2016) \\
\hline 286 & 20120201 & $14: 28: 38$ & 14.28 & 37.89 & 30.0 & 119 & 90 & 14 & 3.6 & Neri\&al.(2014) \\
\hline 287 & 20120208 & $16: 15: 56$ & 14.30 & 37.89 & 12.0 & 200 & 50 & -51 & 3.1 & Totaro\&al.(2016) \\
\hline 288 & 20120225 & $20: 34: 35$ & 13.55 & 38.54 & 12.0 & 20 & 27 & 19 & 4.3 & Neri\&al.(2014) \\
\hline 289 & 20120226 & $16: 17: 23$ & 16.01 & 37.31 & 36.0 & 338 & 70 & -40 & 3.7 & Polonia\&al.(2016) \\
\hline 290 & 20120324 & $20: 34: 59$ & 15.88 & 37.59 & 32.0 & 158 & 84 & -9 & 3.1 & Polonia\&al.(2016) \\
\hline 291 & 20120405 & 03:01:06 & 16.42 & 39.56 & 18.0 & 275 & 42 & -53 & 3.0 & Totaro\&al.(2013) \\
\hline 292 & 20120409 & $23: 29: 02$ & 15.46 & 40.41 & 14.0 & 165 & 58 & -77 & 3.1 & Totaro\&al.(2013) \\
\hline 293 & 20120412 & $13: 20: 28$ & 15.62 & 37.89 & 10.0 & 319 & 90 & 81 & 3.1 & Polonia\&al.(2016) \\
\hline 294 & 20120413 & $06: 21: 33$ & 13.30 & 38.35 & 12.0 & 319 & 29 & -71 & 4.4 & Neri\&al.(2014) \\
\hline 295 & 20120528 & 01:06:27 & 16.12 & 39.89 & 7.0 & 146 & 49 & -90 & 4.3 & Totaro\&al.(2015) \\
\hline 296 & 20120528 & $01: 32: 10$ & 16.10 & 39.90 & 9.3 & 236 & 51 & -27 & 3.1 & Totaro\&al.(2015) \\
\hline 297 & 20120531 & $03: 16: 22$ & 15.57 & 39.89 & 8.0 & 211 & 45 & 2 & 3.0 & Orecchio\&al.(2014) \\
\hline 298 & 20120531 & $20: 18: 23$ & 16.93 & 38.96 & 4.0 & 258 & 82 & -74 & 2.9 & Totaro\&al.(2016) \\
\hline 299 & 20120615 & $06: 27: 25$ & 16.29 & 37.45 & 38.0 & 190 & 80 & 7 & 3.8 & Polonia\&al.(2016) \\
\hline 300 & 20120618 & $03: 17: 12$ & 16.11 & 39.90 & 9.5 & 162 & 29 & -90 & 2.7 & Totaro\&al.(2015) \\
\hline 301 & 20120625 & $10: 52: 51$ & 15.05 & 37.01 & 18.0 & 164 & 77 & -16 & 3.2 & Totaro\&al.(2016) \\
\hline 302 & 20120627 & 01:14:20 & 15.03 & 37.00 & 4.0 & 182 & 90 & 3 & 3.5 & Totaro\&al.(2016) \\
\hline 303 & 20120627 & 01:20:59 & 15.03 & 36.99 & 4.0 & 10 & 81 & -3 & 2.9 & Totaro\&al.(2016) \\
\hline 304 & 20120627 & 02:48:02 & 15.03 & 37.00 & 4.0 & 172 & 90 & -6 & 2.9 & Totaro\&al.(2016) \\
\hline
\end{tabular}


Solid Earth Discuss., https://doi.org/10.5194/se-2018-112

Manuscript under review for journal Solid Earth

Discussion started: 22 October 2018

Solid Earth

(c) Author(s) 2018. CC BY 4.0 License.

\begin{tabular}{|c|c|c|c|c|c|c|c|c|c|c|}
\hline 305 & 20120704 & $11: 12: 12$ & 16.87 & 37.69 & 40.0 & 186 & 74 & 3 & 4.6 & RCMT \\
\hline 306 & 20120715 & $11: 51: 55$ & 16.91 & 39.65 & 18.0 & 118 & 27 & -17 & 3.0 & Orecchio\&al.(2014) \\
\hline 307 & 20120726 & $14: 20: 03$ & 16.34 & 37.90 & 16.0 & 134 & 83 & -19 & 3.1 & Polonia\&al.(2016) \\
\hline 308 & 20120813 & $07: 30: 51$ & 13.73 & 38.52 & 26.5 & 19 & 24 & 63 & 4.2 & RCMT \\
\hline 309 & 20120819 & $17: 45: 08$ & 16.02 & 39.89 & 8.8 & 154 & 46 & -90 & 3.5 & Totaro\&al.(2015) \\
\hline 310 & 20120819 & $21: 28: 29$ & 16.03 & 39.89 & 8.3 & 341 & 37 & -62 & 2.7 & Totaro\&al.(2015) \\
\hline 311 & 20120828 & $23: 12: 15$ & 15.71 & 38.25 & 45.4 & 130 & 10 & -18 & 4.6 & present work \\
\hline 312 & 20120901 & 14:02:45 & 16.03 & 39.89 & 8.4 & 178 & 60 & -69 & 3.4 & Totaro\&al.(2015) \\
\hline 313 & 20120904 & 03:48:03 & 16.03 & 39.90 & 8.3 & 161 & 55 & -81 & 2.8 & Totaro\&al.(2015) \\
\hline 314 & 20120907 & $12: 40: 51$ & 16.03 & 39.89 & 7.9 & 177 & 52 & -70 & 3.3 & Totaro\&al.(2015) \\
\hline 315 & 20120907 & $15: 10: 07$ & 16.02 & 39.89 & 6.0 & 176 & 61 & -62 & 2.8 & Totaro\&al.(2016) \\
\hline 316 & 20120914 & 03:50:11 & 16.03 & 39.90 & 7.9 & 156 & 57 & -90 & 3.6 & Totaro\&al.(2015) \\
\hline 317 & 20120922 & 01:45:02 & 16.02 & 39.91 & 8.0 & 139 & 58 & -84 & 2.7 & Totaro\&al.(2015) \\
\hline 318 & 20120922 & $05: 10: 35$ & 16.61 & 39.78 & 14.0 & 128 & 90 & 71 & 3.5 & Totaro\&al.(2016) \\
\hline 319 & 20120923 & $06: 13: 56$ & 16.02 & 39.91 & 8.4 & 331 & 32 & -90 & 2.7 & Totaro\&al.(2015) \\
\hline 320 & 20120924 & $20: 48: 36$ & 16.03 & 39.92 & 6.4 & 231 & 59 & -42 & 2.7 & Totaro\&al.(2015) \\
\hline 321 & 20120928 & $05: 56: 46$ & 16.10 & 39.91 & 7.3 & 22 & 41 & -80 & 2.8 & Totaro\&al.(2015) \\
\hline 322 & 20121001 & $20: 28: 28$ & 16.03 & 39.91 & 7.7 & 343 & 39 & -82 & 3.5 & Totaro\&al.(2015) \\
\hline 323 & 20121001 & $21: 27: 51$ & 16.02 & 39.91 & 7.8 & 13 & 40 & -43 & 3.3 & Totaro\&al.(2015) \\
\hline 324 & 20121002 & 00:08:57 & 16.03 & 39.91 & 8.6 & 331 & 40 & -80 & 3.3 & Totaro\&al.(2015) \\
\hline 325 & 20121002 & $04: 35: 18$ & 16.03 & 39.91 & 8.2 & 140 & 58 & -78 & 2.8 & Totaro\&al.(2015) \\
\hline 326 & 20121004 & $09: 32: 33$ & 16.02 & 39.90 & 8.0 & 159 & 52 & -84 & 2.9 & Totaro\&al.(2015) \\
\hline 327 & 20121005 & $11: 12: 28$ & 16.03 & 39.90 & 7.6 & 0 & 40 & -73 & 3.0 & Totaro\&al.(2015) \\
\hline 328 & 20121014 & $14: 49: 24$ & 16.02 & 39.91 & 8.7 & 20 & 42 & -40 & 2.7 & Totaro\&al.(2015) \\
\hline 329 & 20121018 & $02: 51: 57$ & 16.03 & 39.90 & 7.8 & 350 & 34 & -90 & 3.3 & Totaro\&al.(2015) \\
\hline 330 & 20121023 & $10: 40: 24$ & 16.03 & 39.91 & 8.4 & 324 & 30 & -82 & 3.1 & Totaro\&al.(2015) \\
\hline 331 & 20121025 & $23: 05: 25$ & 16.03 & 39.89 & 8.8 & 166 & 50 & -77 & 5.0 & Totaro\&al.(2015) \\
\hline 332 & 20121026 & $00: 31: 53$ & 16.00 & 39.89 & 10.0 & 349 & 29 & -49 & 3.0 & Totaro\&al.(2016) \\
\hline 333 & 20121026 & 02:25:09 & 16.03 & 39.92 & 6.6 & 352 & 40 & -81 & 2.9 & Totaro\&al.(2015) \\
\hline 334 & 20121026 & 02:40:08 & 16.02 & 39.88 & 8.1 & 73 & 50 & -50 & 2.8 & Totaro\&al.(2015) \\
\hline 335 & 20121026 & 16:08:58 & 16.03 & 39.89 & 8.9 & 11 & 56 & -23 & 2.7 & Totaro\&al.(2015) \\
\hline 336 & 20121028 & $13: 52: 18$ & 16.02 & 39.93 & 8.5 & 12 & 75 & 27 & 3.1 & Totaro\&al.(2015) \\
\hline 337 & 20121102 & 01:59:34 & 16.47 & 38.78 & 14.0 & 69 & 22 & -50 & 3.1 & Orecchio\&al.(2014) \\
\hline 338 & 20121102 & $17: 50: 44$ & 16.03 & 39.91 & 7.9 & 244 & 58 & -66 & 3.0 & Totaro\&al.(2015) \\
\hline 339 & 20121102 & $17: 58: 47$ & 16.03 & 39.92 & 7.8 & 39 & 52 & -56 & 2.7 & Totaro\&al.(2015) \\
\hline 340 & 20121105 & 12:06:32 & 16.01 & 39.94 & 8.8 & 21 & 71 & -11 & 3.4 & Totaro\&al.(2015) \\
\hline 341 & 20121108 & $11: 11: 57$ & 16.10 & 39.91 & 8.4 & 158 & 16 & -79 & 3.1 & Totaro\&al.(2015) \\
\hline 342 & 20121112 & 03:03:53 & 16.01 & 39.92 & 8.7 & 229 & 42 & 20 & 3.0 & Totaro\&al.(2015) \\
\hline 343 & 20121121 & $06: 43: 25$ & 16.02 & 39.92 & 8.2 & 63 & 60 & -39 & 2.9 & Totaro\&al.(2015) \\
\hline 344 & 20121122 & $01: 59: 52$ & 16.02 & 39.92 & 9.0 & 0 & 41 & -78 & 3.2 & Totaro\&al.(2015) \\
\hline 345 & 20121122 & 09:10:41 & 14.96 & 37.80 & 10.0 & 258 & 65 & 154 & 4.1 & RCMT \\
\hline 346 & 20121122 & $11: 25: 52$ & 14.99 & 37.77 & 20.0 & 6 & 57 & 23 & 4.2 & RCMT \\
\hline 347 & 20121124 & $22: 24: 26$ & 16.02 & 39.92 & 7.9 & 0 & 47 & -79 & 2.8 & Totaro\&al.(2015) \\
\hline 348 & 20121125 & $08: 28: 39$ & 16.02 & 39.92 & 9.4 & 360 & 42 & -72 & 3.5 & Totaro\&al.(2015) \\
\hline 349 & 20121125 & $08: 42: 25$ & 16.03 & 39.93 & 5.5 & 0 & 41 & -74 & 2.9 & Totaro\&al.(2015) \\
\hline 350 & 20121125 & $08: 53: 33$ & 16.01 & 39.89 & 7.6 & 168 & 45 & -90 & 3.0 & Totaro\&al.(2015) \\
\hline
\end{tabular}


Solid Earth Discuss., https://doi.org/10.5194/se-2018-112

Manuscript under review for journal Solid Earth

Discussion started: 22 October 2018

(c) Author(s) 2018. CC BY 4.0 License.

\begin{tabular}{|c|c|c|c|c|c|c|c|c|c|c|}
\hline 351 & 20121125 & $17: 48: 02$ & 16.01 & 39.92 & 9.5 & 7 & 43 & -69 & 3.1 & Totaro\&al.(2015) \\
\hline 352 & 20121128 & $02: 43: 46$ & 16.01 & 39.92 & 9.1 & 45 & 86 & 2 & 2.9 & Totaro\&al.(2015) \\
\hline 353 & 20121211 & $14: 28: 43$ & 16.01 & 39.88 & 9.4 & 339 & 29 & -70 & 3.3 & Totaro\&al.(2015) \\
\hline 354 & 20121213 & 04:44:03 & 16.03 & 39.88 & 8.8 & 20 & 70 & -31 & 3.2 & Totaro\&al.(2015) \\
\hline 355 & 20121218 & 11:03:18 & 16.17 & 39.84 & 2.0 & 130 & 49 & -90 & 3.3 & Totaro\&al.(2016) \\
\hline 356 & 20121218 & 11:05:43 & 16.17 & 39.84 & 4.0 & 158 & 62 & -30 & 3.0 & Totaro\&al.(2016) \\
\hline 357 & 20121226 & $08: 22: 48$ & 16.31 & 39.50 & 8.0 & 41 & 29 & -41 & 3.2 & Totaro\&al.(2016) \\
\hline 358 & 20130104 & 07:50:06 & 14.72 & 37.88 & 12.0 & 318 & 43 & 41 & 4.4 & Neri\&al.(2014) \\
\hline 359 & 20130104 & 10:50:21 & 14.70 & 37.88 & 31.0 & 301 & 81 & -14 & 3.2 & Totaro\&al.(2016) \\
\hline 360 & 20130106 & 07:50:19 & 14.72 & 37.87 & 18.0 & 118 & 63 & -22 & 3.2 & Totaro\&al.(2016) \\
\hline 361 & 20130109 & $16: 10: 34$ & 14.72 & 37.88 & 6.0 & 312 & 78 & -11 & 3.0 & Totaro\&al.(2016) \\
\hline 362 & 20130205 & 22:08:04 & 15.86 & 40.07 & 18.0 & 176 & 71 & -66 & 3.1 & Totaro\&al.(2016) \\
\hline 363 & 20130223 & 19:14:18 & 14.98 & 38.31 & 4.0 & 220 & 79 & -7 & 3.4 & Totaro\&al.(2016) \\
\hline 364 & 20130303 & 23:39:13 & 15.83 & 38.13 & 8.0 & 237 & 57 & -82 & 3.3 & Totaro\&al.(2016) \\
\hline 365 & 20130307 & $22: 36: 59$ & 14.52 & 37.97 & 2.0 & 0 & 50 & -31 & 3.6 & Neri\&al.(2014) \\
\hline 366 & 20130317 & $14: 22: 15$ & 15.89 & 39.62 & 32.0 & 31 & 79 & 48 & 3.3 & Totaro\&al.(2016) \\
\hline 367 & 20130319 & 07:50:06 & 14.51 & 37.98 & 4.0 & 164 & 78 & -43 & 3.4 & Totaro\&al.(2016) \\
\hline 368 & 20130319 & 08:37:04 & 14.51 & 37.98 & 4.0 & 159 & 69 & -39 & 3.3 & Totaro\&al.(2016) \\
\hline 369 & 20130319 & 08:38:45 & 13.56 & 37.84 & 2.0 & 183 & 69 & -8 & 2.8 & Totaro\&al.(2016) \\
\hline 370 & 20130324 & $15: 47: 22$ & 16.50 & 37.76 & 30.0 & 257 & 87 & 178 & 4.6 & RCMT \\
\hline 371 & 20130401 & 03:07:13 & 16.67 & 39.68 & 28.0 & 127 & 68 & 90 & 3.4 & Totaro\&al.(2016) \\
\hline 372 & 20130402 & 01:10:52 & 15.59 & 37.79 & 12.0 & 219 & 85 & -10 & 2.9 & Totaro\&al.(2016) \\
\hline 373 & 20130406 & 04:14:11 & 15.21 & 40.41 & 2.0 & 249 & 47 & 22 & 2.9 & Totaro\&al.(2016) \\
\hline 374 & 20130412 & $17: 50: 00$ & 14.92 & 38.16 & 16.0 & 0 & 67 & 15 & 3.1 & Totaro\&al.(2016) \\
\hline 375 & 20130509 & $20: 41: 22$ & 16.05 & 39.18 & 31.0 & 344 & 82 & -110 & 3.8 & TDMT \\
\hline 376 & 20130622 & 08:41:00 & 19.58 & 40.21 & 10.0 & 324 & 21 & 55 & 4.4 & RCMT \\
\hline 377 & 20130704 & 13:56:06 & 15.61 & 40.49 & 4.0 & 211 & 41 & -42 & 2.9 & Totaro\&al.(2016) \\
\hline 378 & 20130717 & $04: 26: 36$ & 15.83 & 40.02 & 10.0 & 149 & 90 & -72 & 2.9 & Totaro\&al.(2016) \\
\hline 379 & 20130804 & $02: 47: 47$ & 12.85 & 38.69 & 4.0 & 12 & 72 & -11 & 3.3 & Totaro\&al.(2016) \\
\hline 380 & 20130815 & 23:04:58 & 14.91 & 38.14 & 12.0 & 78 & 82 & 57 & 4.5 & Neri\&al.(2014) \\
\hline 381 & 20130815 & 23:06:51 & 14.92 & 38.15 & 12.0 & 77 & 82 & 55 & 4.6 & Neri\&al.(2014) \\
\hline 382 & 20130819 & $05: 48: 23$ & 14.26 & 37.70 & 20.0 & 23 & 59 & -14 & 3.0 & Totaro\&al.(2016) \\
\hline 383 & 20130828 & 09:07:00 & 14.31 & 38.85 & 6.0 & 210 & 72 & 12 & 3.6 & Totaro\&al.(2016) \\
\hline 384 & 20130917 & $22: 56: 38$ & 15.80 & 40.79 & 8.0 & 339 & 69 & 1 & 3.3 & Totaro\&al.(2016) \\
\hline 385 & 20130917 & 23:38:49 & 15.81 & 40.79 & 10.0 & 133 & 72 & -83 & 3.4 & Totaro\&al.(2016) \\
\hline 386 & 20130921 & 13:18:02 & 15.78 & 40.79 & 16.0 & 342 & 57 & -34 & 3.2 & Totaro\&al.(2016) \\
\hline 387 & 20130926 & 12:19:59 & 17.23 & 39.13 & 22.0 & 188 & 12 & 52 & 3.1 & Totaro\&al.(2016) \\
\hline 388 & 20131003 & $18: 22: 25$ & 13.49 & 38.47 & 14.0 & 20 & 51 & 0 & 3.4 & Totaro\&al.(2016) \\
\hline 389 & 20131007 & 04:44:05 & 15.08 & 38.13 & 6.0 & 84 & 63 & -29 & 2.8 & Totaro\&al.(2016) \\
\hline 390 & 20131008 & 10:33:20 & 15.82 & 40.02 & 2.0 & 55 & 60 & -10 & 2.7 & Totaro\&al.(2016) \\
\hline 391 & 20131009 & 08:14:49 & 15.09 & 37.61 & 4.0 & 33 & 81 & 8 & 2.9 & Totaro\&al.(2016) \\
\hline 392 & 20131009 & $08: 33: 22$ & 15.07 & 37.61 & 10.0 & 258 & 90 & 1 & 3.2 & Totaro\&al.(2016) \\
\hline 393 & 20131018 & 08:03:44 & 14.90 & 38.11 & 14.0 & 258 & 79 & -61 & 3.0 & Totaro\&al.(2016) \\
\hline 394 & 20131018 & 11:05:21 & 14.97 & 36.79 & 2.0 & 173 & 82 & 3 & 2.9 & Totaro\&al.(2016) \\
\hline 395 & 20131018 & 15:08:31 & 10.83 & 35.70 & 12.0 & 99 & 51 & -179 & 4.8 & CMT \\
\hline 396 & 20131018 & $20: 50: 52$ & 15.22 & 40.80 & 14.0 & 319 & 41 & -76 & 3.1 & Totaro\&al.(2016) \\
\hline
\end{tabular}


Solid Earth Discuss., https://doi.org/10.5194/se-2018-112

Manuscript under review for journal Solid Earth

Discussion started: 22 October 2018

(c) Author(s) 2018. CC BY 4.0 License.

\begin{tabular}{|c|c|c|c|c|c|c|c|c|c|c|}
\hline 397 & 20131019 & 11:08:03 & 15.18 & 40.59 & 14.0 & 112 & 30 & 58 & 3.0 & Totaro\&al.(2016) \\
\hline 398 & 20131021 & $19: 37: 00$ & 10.93 & 35.60 & 10.0 & 89 & 71 & 165 & 4.5 & RCMT \\
\hline 399 & 20131103 & $14: 33: 41$ & 15.18 & 40.60 & 2.0 & 87 & 58 & -80 & 2.7 & Totaro\&al.(2016) \\
\hline 400 & 20131105 & $05: 06: 39$ & 14.91 & 37.69 & 22.0 & 84 & 57 & -11 & 3.1 & Totaro\&al.(2016) \\
\hline 401 & 20131105 & $05: 29: 58$ & 14.92 & 37.70 & 18.0 & 99 & 72 & -14 & 3.0 & Totaro\&al.(2016) \\
\hline 402 & 20131105 & $17: 25: 23$ & 16.01 & 39.88 & 8.0 & 80 & 51 & -45 & 3.0 & Totaro\&al.(2016) \\
\hline 403 & 20131105 & $17: 26: 45$ & 16.01 & 39.88 & 10.0 & 328 & 32 & -79 & 3.4 & Totaro\&al.(2016) \\
\hline 404 & 20131210 & 20:39:39 & 15.45 & 39.72 & 22.0 & 172 & 19 & 69 & 3.1 & Totaro\&al.(2016) \\
\hline 405 & 20131214 & 21:49:05 & 14.74 & 37.76 & 30.0 & 53 & 67 & -27 & 3.4 & Totaro\&al.(2016) \\
\hline 406 & 20131215 & 03:57:33 & 14.94 & 36.67 & 15.0 & 83 & 47 & 143 & 4.1 & RCMT \\
\hline 407 & 20131223 & $04: 20: 39$ & 15.57 & 38.22 & 2.0 & 31 & 61 & -60 & 3.5 & Neri\&al.(2014) \\
\hline 408 & 20131223 & $16: 17: 11$ & 15.04 & 38.18 & 16.0 & 113 & 63 & -33 & 3.1 & Totaro\&al.(2016) \\
\hline 409 & 20140102 & 06:13:18 & 15.04 & 38.18 & 12.0 & 103 & 38 & 8 & 3.0 & Totaro\&al.(2016) \\
\hline 410 & 20140114 & 03:43:42 & 14.92 & 38.37 & 12.0 & 315 & 78 & 171 & 4.1 & RCMT \\
\hline 411 & 20140114 & 04:35:00 & 14.94 & 38.36 & 11.0 & 308 & 47 & 159 & 4.2 & RCMT \\
\hline 412 & 20140122 & 19:35:01 & 15.12 & 40.44 & 8.0 & 61 & 32 & -61 & 3.6 & Totaro\&al.(2016) \\
\hline 413 & 20140127 & $21: 39: 32$ & 15.93 & 40.12 & 10.0 & 38 & 58 & -19 & 3.0 & Totaro\&al.(2016) \\
\hline 414 & 20140218 & $21: 44: 19$ & 13.82 & 37.63 & 4.0 & 250 & 79 & 33 & 3.3 & Totaro\&al.(2016) \\
\hline 415 & 20140219 & 06:58:05 & 15.11 & 38.17 & 8.0 & 34 & 62 & 17 & 3.0 & Totaro\&al.(2016) \\
\hline 416 & 20140301 & 01:48:50 & 15.22 & 40.24 & 4.0 & 19 & 27 & 40 & 2.9 & Totaro\&al.(2016) \\
\hline 417 & 20140301 & $11: 51: 25$ & 15.29 & 40.25 & 6.0 & 305 & 68 & 8 & 2.7 & Totaro\&al.(2016) \\
\hline 418 & 20140303 & 06:26:04 & 15.01 & 40.40 & 8.0 & 287 & 47 & -64 & 3.0 & Totaro\&al.(2016) \\
\hline 419 & 20140308 & 14:19:05 & 15.81 & 39.77 & 16.0 & 280 & 79 & 46 & 3.0 & Totaro\&al.(2016) \\
\hline 420 & 20140308 & $20: 52: 51$ & 14.89 & 37.96 & 32.0 & 13 & 47 & -40 & 3.8 & Neri\&al.(2014) \\
\hline 421 & 20140314 & 03:32:24 & 14.81 & 38.22 & 2.0 & 19 & 90 & -1 & 3.0 & Totaro\&al.(2016) \\
\hline 422 & 20140314 & 03:37:16 & 14.80 & 38.20 & 6.0 & 331 & 62 & 4 & 2.8 & Totaro\&al.(2016) \\
\hline 423 & 20140323 & $18: 31: 52$ & 16.48 & 37.47 & 38.0 & 177 & 61 & 21 & 3.6 & Totaro\&al.(2016) \\
\hline 424 & 20140325 & $07: 56: 52$ & 16.54 & 39.29 & 28.0 & 276 & 59 & -50 & 3.6 & Totaro\&al.(2016) \\
\hline 425 & 20140405 & $10: 24: 46$ & 17.18 & 38.82 & 64.0 & 92 & 59 & -168 & 4.8 & RCMT \\
\hline 426 & 20140412 & 06:53:05 & 13.88 & 37.82 & 2.0 & 360 & 81 & -1 & 3.1 & Totaro\&al.(2016) \\
\hline 427 & 20140417 & 21:52:26 & 15.21 & 38.23 & 2.0 & 12 & 90 & 2 & 2.8 & Totaro\&al.(2016) \\
\hline 428 & 20140503 & 20:04:06 & 16.11 & 39.90 & 4.0 & 232 & 31 & -70 & 3.0 & Totaro\&al.(2016) \\
\hline 429 & 20140506 & $08: 24: 42$ & 16.07 & 39.91 & 4.0 & 241 & 51 & -90 & 3.0 & Totaro\&al.(2016) \\
\hline 430 & 20140507 & 06:20:00 & 19.78 & 37.75 & 10.0 & 181 & 68 & 16 & 4.3 & RCMT \\
\hline 431 & 20140507 & 17:08:35 & 16.02 & 39.89 & 8.0 & 160 & 49 & -58 & 2.9 & Totaro\&al.(2016) \\
\hline 432 & 20140517 & $22: 38: 44$ & 15.61 & 37.41 & 30.0 & 191 & 78 & -38 & 3.1 & Totaro\&al.(2016) \\
\hline 433 & 20140519 & 00:59:23 & 19.94 & 40.91 & 20.0 & 59 & 49 & 11 & 5.1 & CMT \\
\hline 434 & 20140520 & $04: 43: 26$ & 19.86 & 40.92 & 2.0 & 63 & 74 & 8 & 4.4 & RCMT \\
\hline 435 & 20140604 & 21:20:41 & 16.00 & 39.88 & 8.0 & 159 & 58 & -90 & 3.6 & Totaro\&al.(2016) \\
\hline 436 & 20140606 & $13: 41: 38$ & 16.09 & 39.90 & 4.0 & 155 & 31 & -90 & 3.9 & Totaro\&al.(2016) \\
\hline 437 & 20140607 & 15:00:49 & 15.10 & 38.09 & 10.0 & 285 & 73 & 7 & 3.7 & Neri\&al.(2014) \\
\hline 438 & 20140607 & $15: 13: 20$ & 15.10 & 38.08 & 10.0 & 238 & 39 & -49 & 2.6 & Totaro\&al.(2016) \\
\hline 439 & 20140617 & $12: 25: 02$ & 16.98 & 38.96 & 2.0 & 239 & 40 & -90 & 2.7 & Totaro\&al.(2016) \\
\hline 440 & 20140627 & $02: 56: 49$ & 14.64 & 37.83 & 14.0 & 360 & 37 & -26 & 3.3 & Totaro\&al.(2016) \\
\hline 441 & 20140629 & $04: 24: 28$ & 15.60 & 39.92 & 14.0 & 248 & 22 & 1 & 3.8 & Totaro\&al.(2016) \\
\hline 442 & 20140629 & $05: 32: 22$ & 15.60 & 39.91 & 6.0 & 47 & 65 & -47 & 2.6 & Totaro\&al.(2016) \\
\hline
\end{tabular}


Solid Earth Discuss., https://doi.org/10.5194/se-2018-112

Manuscript under review for journal Solid Earth

Discussion started: 22 October 2018

(c) Author(s) 2018. CC BY 4.0 License.

\begin{tabular}{|c|c|c|c|c|c|c|c|c|c|c|}
\hline 443 & 20140629 & $05: 42: 56$ & 15.59 & 39.91 & 14.0 & 240 & 21 & -21 & 3.3 & Totaro\&al.(2016) \\
\hline 444 & 20140702 & $18: 49: 46$ & 15.17 & 40.59 & 2.0 & 71 & 49 & -70 & 3.1 & Totaro\&al.(2016) \\
\hline 445 & 20140707 & $17: 44: 15$ & 15.50 & 40.72 & 12.0 & 32 & 64 & 30 & 3.3 & Totaro\&al.(2016) \\
\hline 446 & 20140708 & $05: 02: 43$ & 16.12 & 39.90 & 2.0 & 347 & 51 & -83 & 2.7 & Totaro\&al.(2016) \\
\hline 447 & 20140711 & $21: 57: 58$ & 15.39 & 40.49 & 10.0 & 344 & 82 & -49 & 3.5 & Totaro\&al.(2016) \\
\hline 448 & 20140724 & $01: 12: 51$ & 15.02 & 38.09 & 30.0 & 100 & 90 & -16 & 3.2 & Totaro\&al.(2016) \\
\hline 449 & 20140731 & $03: 29: 29$ & 16.11 & 39.91 & 4.0 & 349 & 58 & -82 & 3.4 & Totaro\&al.(2016) \\
\hline 450 & 20140806 & 08:16:21 & 15.83 & 40.58 & 8.0 & 323 & 83 & -9 & 3.0 & Totaro\&al.(2016) \\
\hline 451 & 20140812 & $20: 15: 34$ & 16.42 & 40.45 & 16.0 & 330 & 44 & -54 & 3.9 & RCMT \\
\hline 452 & 20140813 & 10:08:09 & 16.43 & 40.44 & 4.0 & 160 & 63 & -25 & 3.0 & Totaro\&al.(2016) \\
\hline 453 & 20140816 & $05: 00: 12$ & 13.42 & 38.53 & 10.0 & 161 & 86 & 59 & 3.4 & TDMT \\
\hline 454 & 20140826 & 01:19:46 & 14.33 & 37.95 & 14.0 & 298 & 20 & -90 & 3.5 & Totaro\&al.(2016) \\
\hline 455 & 20140905 & 10:10:19 & 18.76 & 39.19 & 10.0 & 334 & 39 & -56 & 4.1 & RCMT \\
\hline 456 & 20140907 & $09: 56: 25$ & 19.88 & 37.61 & 10.0 & 329 & 33 & 104 & 4.6 & RCMT \\
\hline 457 & 20140919 & $05: 32: 38$ & 14.81 & 38.49 & 14.0 & 66 & 78 & 25 & 3.2 & Totaro\&al.(2016) \\
\hline 458 & 20140924 & 15:39:09 & 15.85 & 39.74 & 24.0 & 51 & 80 & -39 & 3.2 & Totaro\&al.(2016) \\
\hline 459 & 20140926 & $23: 38: 11$ & 16.50 & 36.78 & 40.0 & 267 & 75 & 170 & 4.2 & RCMT \\
\hline 460 & 20141009 & $22: 58: 28$ & 14.85 & 38.51 & 10.0 & 76 & 40 & 80 & 4.1 & RCMT \\
\hline 461 & 20141010 & $16: 16: 18$ & 15.14 & 38.09 & 34.0 & 60 & 90 & -76 & 3.1 & Totaro\&al.(2016) \\
\hline 462 & 20141010 & $16: 27: 13$ & 15.14 & 38.09 & 30.0 & 349 & 72 & -31 & 2.8 & Totaro\&al.(2016) \\
\hline 463 & 20141013 & 03:34:47 & 16.46 & 39.37 & 10.0 & 18 & 77 & -73 & 2.8 & Totaro\&al.(2016) \\
\hline 464 & 20141014 & $00: 50: 55$ & 16.63 & 38.95 & 14.0 & 150 & 74 & -1 & 2.9 & Totaro\&al.(2016) \\
\hline 465 & 20141025 & 20:09:48 & 15.95 & 38.17 & 15.0 & 275 & 68 & -79 & 3.3 & TDMT \\
\hline 466 & 20141116 & $12: 38: 42$ & 15.08 & 38.24 & 6.0 & 276 & 84 & 1 & 2.8 & Totaro\&al.(2016) \\
\hline 467 & 20141127 & 09:09:44 & 16.49 & 38.86 & 20.0 & 28 & 39 & -81 & 3.2 & Totaro\&al.(2016) \\
\hline 468 & 20141228 & $21: 43: 38$ & 16.36 & 39.29 & 10.0 & 179 & 49 & -69 & 4.2 & Totaro\&al.(2016) \\
\hline 469 & 20150110 & $03: 40: 38$ & 13.79 & 38.07 & 4.0 & 327 & 81 & 1 & 2.9 & Totaro\&al.(2016) \\
\hline 470 & 20150120 & $07: 17: 22$ & 15.57 & 38.11 & 18.0 & 199 & 38 & 32 & 3.3 & Totaro\&al.(2016) \\
\hline 471 & 20150208 & 19:39:22 & 15.22 & 37.35 & 22.0 & 87 & 52 & -50 & 3.1 & Totaro\&al.(2016) \\
\hline 472 & 20150211 & 01:42:09 & 14.75 & 38.05 & 4.0 & 127 & 37 & -57 & 3.0 & Totaro\&al.(2016) \\
\hline 473 & 20150211 & 03:57:01 & 14.74 & 38.05 & 4.0 & 272 & 70 & -37 & 3.1 & Totaro\&al.(2016) \\
\hline 474 & 20150312 & $15: 29: 04$ & 16.23 & 38.43 & 2.0 & 230 & 59 & -78 & 3.3 & Totaro\&al.(2016) \\
\hline 475 & 20150328 & 22:07:51 & 16.21 & 38.09 & 20.0 & 233 & 79 & 79 & 3.1 & Totaro\&al.(2016) \\
\hline 476 & 20150329 & $10: 48: 46$ & 16.21 & 38.09 & 12.0 & 52 & 76 & -83 & 3.5 & Totaro\&al.(2016) \\
\hline 477 & 20150420 & 01:07:43 & 15.12 & 37.80 & 3.0 & 178 & 83 & -164 & 3.5 & TDMT \\
\hline 478 & 20150430 & $05: 35: 21$ & 15.39 & 37.86 & 26.0 & 160 & 61 & 44 & 2.9 & Totaro\&al.(2016) \\
\hline 479 & 20150511 & $08: 26: 32$ & 16.80 & 37.33 & 40.0 & 184 & 62 & 20 & 4.5 & RCMT \\
\hline 480 & 20150511 & $08: 26: 30$ & 16.79 & 37.18 & 44.0 & 187 & 69 & -9 & 4.2 & present work \\
\hline 481 & 20150521 & $15: 31: 18$ & 19.85 & 37.68 & 15.0 & 207 & 72 & 177 & 4.4 & RCMT \\
\hline 482 & 20150521 & $22: 13: 22$ & 14.72 & 38.45 & 2.0 & 281 & 53 & -10 & 2.9 & Totaro\&al.(2016) \\
\hline 483 & 20150522 & $06: 31: 16$ & 19.84 & 37.67 & 10.0 & 206 & 80 & 178 & 4.2 & RCMT \\
\hline 484 & 20150524 & 06:00:00 & 16.03 & 37.96 & 62.0 & 23 & 62 & -3 & 4.1 & present work \\
\hline 485 & 20150611 & $04: 31: 45$ & 14.01 & 37.88 & 8.0 & 148 & 60 & -54 & 2.7 & Totaro\&al.(2016) \\
\hline 486 & 20150617 & 09:44:07 & 14.15 & 37.66 & 24.0 & 332 & 82 & 8 & 3.4 & Totaro\&al.(2016) \\
\hline 487 & 20150703 & 01:07:24 & 16.52 & 39.92 & 16.0 & 188 & 60 & 62 & 3.2 & Totaro\&al.(2016) \\
\hline 488 & 20150715 & 04:19:11 & 14.43 & 37.22 & 18.0 & 164 & 79 & 11 & 3.1 & Totaro\&al.(2016) \\
\hline
\end{tabular}


Solid Earth Discuss., https://doi.org/10.5194/se-2018-112

Manuscript under review for journal Solid Earth

Discussion started: 22 October 2018

(c) Author(s) 2018. CC BY 4.0 License.

\begin{tabular}{|l|l|l|l|l|l|l|l|l|l|l|}
489 & 20150715 & $16: 29: 49$ & 15.05 & 37.62 & 10.0 & 214 & 90 & -11 & 3.0 & Totaro\&al.(2016) \\
\hline 490 & 20150726 & $13: 39: 38$ & 14.76 & 38.50 & 6.0 & 204 & 84 & 48 & 2.9 & Totaro\&al.(2016) \\
\hline 491 & 20150801 & $02: 46: 51$ & 15.86 & 37.64 & 42.0 & 195 & 90 & 9 & 3.4 & Totaro\&al.(2016) \\
\hline 492 & 20150803 & $07: 27: 49$ & 16.49 & 39.15 & 16.0 & 242 & 19 & -33 & 3.9 & Totaro\&al.(2016) \\
\hline 493 & 20150803 & $13: 52: 37$ & 16.14 & 37.39 & 38.0 & 205 & 59 & 1 & 3.6 & Totaro\&al.(2016) \\
\hline 494 & 20150804 & $23: 36: 31$ & 14.15 & 37.64 & 10.0 & 168 & 84 & 14 & 3.2 & Totaro\&al.(2016) \\
\hline 495 & 20150806 & $01: 59: 43$ & 15.19 & 38.24 & 8.0 & 214 & 76 & -61 & 3.1 & Totaro\&al.(2016) \\
\hline 496 & 20150808 & $22: 46: 24$ & 14.27 & 38.55 & 8.0 & 173 & 90 & 14 & 3.8 & Totaro\&al.(2016) \\
\hline 497 & 20150818 & $05: 59: 15$ & 15.45 & 40.64 & 12.0 & 326 & 70 & -45 & 3.0 & Totaro\&al.(2016) \\
\hline 498 & 20150826 & $04: 28: 36$ & 16.91 & 38.79 & 24.0 & 10 & 90 & -33 & 3.3 & Totaro\&al.(2016) \\
\hline 499 & 20150829 & $20: 25: 13$ & 12.12 & 38.54 & 14.0 & 332 & 81 & 8 & 4.0 & Totaro\&al.(2016) \\
\hline 500 & 20150920 & $22: 27: 58$ & 15.61 & 37.16 & 30.0 & 226 & 58 & -2 & 3.8 & Totaro\&al.(2016) \\
\hline 501 & 20151220 & $09: 46: 00$ & 13.58 & 38.35 & 10.0 & 24 & 20 & 59 & 4.4 & RCMT \\
\hline 502 & 20151229 & $14: 15: 53$ & 19.89 & 37.42 & 10.0 & 107 & 58 & -14 & 4.1 & RCMT \\
\hline 503 & 20160102 & $12: 36: 24$ & 12.03 & 36.46 & 10.0 & 268 & 79 & -178 & 4.2 & RCMT \\
\hline 504 & 20160113 & $17: 01: 30$ & 14.67 & 36.14 & 10.0 & 262 & 79 & 175 & 4.2 & RCMT \\
\hline 505 & 20160208 & $15: 35: 43$ & 14.90 & 36.99 & 10.0 & 280 & 42 & 178 & 4.5 & RCMT \\
\hline 506 & 20160306 & $08: 12: 36$ & 16.74 & 38.20 & 39.0 & 248 & 75 & 158 & 4.0 & TDMT \\
\hline 507 & 20160329 & $01: 05: 33$ & 19.96 & 37.25 & 17.0 & 338 & 19 & 121 & 5.4 & CMT \\
\hline
\end{tabular}

505

506 
Solid Earth Discuss., https://doi.org/10.5194/se-2018-112

Manuscript under review for journal Solid Earth

Discussion started: 22 October 2018

(c) Author(s) 2018. CC BY 4.0 License.

Data availability. Data used in the present study were collected from the databases of Istituto

508 Nazionale di Geofisica e Vulcanologia (www.ingv.it) and from catalogs and bibliographic sources

509 indicated in detail in the article.

510

511 Author contributions. All authors contributed to the scientific content, interpretations, message of

512 the paper, and the discussions. CT primarily worked on stress inversion of earthquake fault -plane

513 solutions, BO and DP on hypocenter locations in $3 \mathrm{D}$ velocity structures with the different

514 algorithms, GN linked the different contributions and produced the final paper with the support of 515 the other authors.

Competing interests. The authors declare that they have no conflict of interests.

Acknowledgements: This work has been performed in the framework of activity of the Research

Unit UNIME of CRUST - Interuniversity Center for 3D Seismotectonics with territorial applications. Some figures were created using Generic Mapping Tools by Wessel and Smith (1991).

\section{References}

Anderson, H.: Is the Adriatic an African promontory?, Geology, 15(3), 212-215, 1987.

Anderson, H., and Jackson, J.: Active tectonics of the Adriatic region, Geophys. J. Int., 91(3), 937$983,1987$.

Argnani, A.: Evolution of the southern Tyrrhenian slab tear and active tectonics along the western 
Solid Earth Discuss., https://doi.org/10.5194/se-2018-112

Manuscript under review for journal Solid Earth

Discussion started: 22 October 2018

(c) Author(s) 2018. CC BY 4.0 License.

534 Battaglia, M., Murray, M. H., Serpelloni, E., and Bürgmann, R.: The Adriatic region: An 535 independent microplate within the Africa-Eurasia collision zone, Geophys. Res. Lett., 31(9). doi:10.1029/2004GL019723, 2004.

Billi, A., Presti, D., Faccenna, C., Neri, G., and Orecchio, B.: Seismotectonics of the Nubia plate compressive margin in the south Tyrrhenian region, Italy: Clues for subduction inception, J.

Geophys. Res., 112(B8), 2007.

541

Billi, A., Presti, D., Orecchio, B., Faccenna, C., and Neri, G.: Incipient extension along the active convergent margin of Nubia in Sicily, Italy: Cefalù-Etna seismic zone, Tectonics, 29(4), 2010.

Billi, A., Faccenna, C., Bellier, O., Minelli, L., Neri, G., Piromallo, C., Presti, D., Scrocca, D., and Serpelloni, E.: Recent tectonic reorganization of the Nubia-Eurasia convergent boundary heading for the closure of the western Mediterranean, Bull. Soc. Geol. Fr., 182(4), 279-303, 2011.

Cadet, J. P., and Funiciello, R.: Carte Géodynamique de la Méditerranée: Geodynamique Map of the Mediterranean, Commission for the Geological Map of the World, 2004.

Calò, M., and Parisi, L.: Evidences of a lithospheric fault zone in the Sicily Channel continental rift (southern Italy) from instrumental seismicity data, Geophys. J. Int., 199(1), 219-225, 2014.

Cavallaro, D., Monaco, C., Polonia, A., Sulli, A., and Di Stefano, A.: Evidence of positive tectonic inversion in the north-central sector of the Sicily Channel (Central Mediterranean), Nat. Hazards, 86(2), 233-251, 2017. 
Solid Earth Discuss., https://doi.org/10.5194/se-2018-112

Manuscript under review for journal Solid Earth

Discussion started: 22 October 2018

(c) Author(s) 2018. CC BY 4.0 License.

Chiarabba, C., and Palano, M.: Progressive migration of slab break-off along the southern Tyrrhenian plate boundary: Constraints for the present day kinematics, J Geodyn., 105, 51-61, 2017.

Christova, C. V.: Spatial distribution of the contemporary stress field in the Kurile Wadati-Benioff zone by inversion of earthquake focal mechanisms, J Geodyn., 83, 1-17, 2015.

D’Agostino, N., Avallone, A., Cheloni, D., D’Anastasio, E., Mantenuto, S., and Selvaggi, G.: Active tectonics of the Adriatic region from GPS and earthquake slip vectors, J. Geophys. Res., 113, B12413, doi:10.1029/2008JB005860, 2008.

D’Agostino, N., D’Anastasio, E., Gervasi, A., Guerra, I., Nedimovic, M.R., Seeber, L., and Steckler, M. Forearc extension and slow rollback of the Calabria Arc from GPS measurements, Geophys. Res. Lett., 38, L17304, doi:10.1029/2011GL048270, 2011.

D’Amico, S., Orecchio, B., Presti, D., Zhu, L., Herrmann, R. B., and Neri, G.: Broadband waveform inversion of moderate earthquakes in the Messina Straits, southern Italy, Phys. Earth Planet. Inter., 179(3-4), 97-106, 2010.

D'Amico, S., Orecchio, B., Presti, D., Gervasi, A., Zhu, L., Guerra, I., Neri, G., and Herrmann, R. B.: Testing the stability of moment tensor solutions for small earthquakes in the Calabro-Peloritan Arc region (southern Italy), B. Geofis. Teor. Appl., doi:10.4430/bgta0009, 2011.

Evans, J.R., Eberhart-Phillips, D., and Thurber, C.H.: User's Manual for Simulps12for Imagingvp andVp/Vs: A Derivative of the "Thurber" Tomographic InversionSimul3 for Local Earthquakes and Explosions. Open-file Report. US GeologicalSurvey, Menlo Park, 94-431, 1994. 
Solid Earth Discuss., https://doi.org/10.5194/se-2018-112

Manuscript under review for journal Solid Earth

Discussion started: 22 October 2018

(c) Author(s) 2018. CC BY 4.0 License.

586 Gallais, F., Graindorge, D., Gutscher, M. A., and Klaeschen, D.: Propagation of a lithospheric tear

Sicily (Southern Italy), Tectonophysics, 602, 141-152, 2013.

Gephart, J. W.: FMSI: A FORTRAN program for inverting fault/slickenside and earthquake focal 1990.

Gephart, J. W., and Forsyth, D. W.: An improved method for determining the regional stress tensor

using earthquake focal mechanism data: application to the San Fernando earthquake sequence, J.

Geophys. Res., 89(B11), 9305-9320, 1984.

Ghisetti, F. C., Gorman, A. R., Grasso, M., and Vezzani, L.: Imprint of foreland structure on the deformation of a thrust sheet: The Plio-Pleistocene Gela Nappe (southern Sicily, Italy), Tectonics, 28(4), 2009.

601

Gillard, D., Wyss, M., and Okubo, P.: Type of faulting and orientation of stress and strain as a function of space and time in Kilauea's south flank. Hawaii, J. Geophys. Res., 101, 16025-16042, 1996. 
Solid Earth Discuss., https://doi.org/10.5194/se-2018-112

Manuscript under review for journal Solid Earth

Discussion started: 22 October 2018

(c) Author(s) 2018. CC BY 4.0 License.

611 Gutscher, M. A., Kopp, H., Krastel, S., Bohrmann, G., Garlan, T., Zaragosi, S., Klaucke, I.,

612 Wintersteller, P., Loubrieu, B., Le Faou, Y., San Pedro, L., Dominguez, S., Roverei, M., Mercier de

613 Lepinay, B., Ranero, C., and Sallares, V. Active tectonics of the Calabrian subduction revealed by

614 new multi-beam bathymetric data and high-resolution seismic profiles in the Ionian Sea (Central

615 Mediterranean), Earth Planet. Sci. Lett., 461, 61-72, 2017.

616

617 Lavecchia, G., Ferrarini, F., de Nardis, R., Visini, F., and Barbano, M. S.: Active thrusting as a

618 possible seismogenic source in Sicily (Southern Italy): Some insights from integrated structural-

619 kinematic and seismological data, Tectonophysics, 445(3-4), 145-167, 2007.

620

Li, H., Michelini, A., Zhu, L., Bernardi, F., and Spada, M. Crustal velocity structure in Italy from

analysis of regional seismic waveforms, Bull. Seism. Soc. Am., 97(6), 2024-2039, 2007.

623

Malinverno, A., and Ryan, W. B.: Extension in the Tyrrhenian Sea and shortening in the Apennines

as result of arc migration driven by sinking of the lithosphere, Tectonics, 5(2), 227-245, 1986.

Marotta, A. M., Splendore, R., and Barzaghi, R.: An application of model uncertainty statistical

Michael, A.J.: Use of focal mechanisms to determine stress: a control study, J. Geophys. Res. 92, $357-368,1987$.

632

633 Minelli, L., and Faccenna, C.: Evolution of the Calabrian accretionary wedge (Central 634 Mediterranean), Tectonics, 29, TC4004, doi: 10.1029/2009TC002562, 2010. 
Solid Earth Discuss., https://doi.org/10.5194/se-2018-112

Manuscript under review for journal Solid Earth

Discussion started: 22 October 2018

(c) Author(s) 2018. CC BY 4.0 License.

653

Musumeci, C., Scarfi, L., Palano, M., and Patanè, D.: Foreland segmentation along an active convergent margin: New constraints in southeastern Sicily (Italy) from seismic and geodetic observations, Tectonophysics, 630, 137-149, 2014.

Neri, G., Barberi, G., Oliva, G., and Orecchio, B.: Spatial variations of seismogenic stress orientations in Sicily, south Italy, Phys. Earth Planet. Inter., 148(2-4), 175-191, 2005.

Neri, G., Orecchio, B., Totaro, C., Falcone, G., and Presti, D.: Subduction beneath southern Italy close the ending: results from seismic tomography, Seismol. Res. Lett., 80, 63-70, 2009.

Neri, G., Marotta, A. M., Orecchio, B., Presti, D., Totaro, C., Barzaghi, R., and Borghi, A.: How lithospheric subduction changes along the Calabrian Arc in southern Italy: geophysical evidences. Int. J. Earth Sci., 101(7), 1949-1969, 2012.

Nijholt, N., Govers, R., and Wortel, R.: On the forces that drive and resist deformation of the southcentral Mediterranean: a mechanical model study, Geophys. J. Int., https://doi.org/10.1093/gji/ggy144, 2018.

Nocquet, J.: Present-day kinematics of the Mediterranean: a comprehensive overview of GPS results, Tectonophysics, 579, 220-242, 2012.

Oldow, J.S., Ferranti, L., Lewis, D. S., Campbell, J. K., d'Argenio, B., Catalano, R., Pappone, G., Carmignani, L., Conti, P., and Aiken, C. L. V.: Active fragmentation of Adria, the north African promontory, central Mediterranean orogen, Geology, 30, 779-782, 2002. 
Solid Earth Discuss., https://doi.org/10.5194/se-2018-112

Manuscript under review for journal Solid Earth

Discussion started: 22 October 2018

661

Oldow, J. S., and Ferranti, L.: Fragmentation of Adria and active decollement tectonics within the southern peri-Tyrrhenian orogen, Italy. In The Adria Microplate: GPS Geodesy, Tectonics and Hazards, 269-286, Springer, Dordrecht, 2006.

Orecchio, B., Presti, D., Totaro, C., Guerra, I., and Neri, G.: Imaging the velocity structure of the Calabrian Arc region (South Italy) through the integration of different seismological data, Boll. Geofis. Teor. Appl., 52, 625-638, 2011.

Orecchio, B., Presti, D., Totaro, C., and Neri, G.: What earthquakes say concerning residual subduction and STEP dynamics in the Calabrian Arc region, south Italy. Geophys. J. Int., 199(3), 1929-1942, 2014.

Orecchio, B., Presti, D., Totaro, C., D’Amico, S., and Neri, G.: Investigating slab edge kinematics through seismological data: The northern boundary of the Ionian subduction system (south Italy), J. Geodyn., 88, 23-35, 2015.

Orecchio, B., Aloisi, M., Cannavò, F., Palano, M., Presti, D., Pulvirenti, F., Totaro, C., Siligato, G., and Neri, G.: Present-day kinematics and deformation processes in the southern Tyrrhenian region: new insights on the northern Sicily extensional belt, It. Jour. Geosci., 136(3), 418-433, 2017.

Palano, M., Ferranti, L., Monaco, C., Mattia, M., Aloisi, M., Bruno, V., Cannavò, F., and Siligato, G.: GPS velocity and strain fields in Sicily and southern Calabria, Italy: updated geodetic constraints on tectonic block interaction in the central Mediterranean, J. Geophys. Res., 117(B7), 2012. 
Solid Earth Discuss., https://doi.org/10.5194/se-2018-112

Manuscript under review for journal Solid Earth

Discussion started: 22 October 2018

(c) Author(s) 2018. CC BY 4.0 License.

Palano, M., González, P. J., and Fernández, J.: The diffuse plate boundary of Nubia and Iberia in

the Western Mediterranean: crustal deformation evidence for viscous coupling and fragmented

Palano M., Schiavone D., Loddo M., Neri M., Presti D., Quarto R., Totaro C., and Neri G. Active

Sicily): Insights from a multidisciplinary approach, Tectonophysics, 657, 205-218,

Parker, R. L., and McNutt, M. K. Statistics for the one-norm misfit measure, J. Geophys. Res.,

Pérouse, E., Chamot-Rooke, N., Rabaute, A., Briole, P., Jouanne, F., Georgiev, I., and Dimitrov,

D.: Bridging onshore and offshore presentday kinematics of central and eastern Mediterranean:

Implications for crustal dynamics and mantle flow, Geochem. Geophys. Geosyst, 13, 9, 2012.

Polonia, A., Torelli, L., Mussoni, P., Gasperini, L., Artoni, A., and Klaeschen, D.: The Calabrian

Arc subduction complex in the Ionian Sea: Regional architecture, active deformation, and seismic hazard, Tectonics, 30(5), 2011.

Polonia, A., Torelli, L., Artoni, A., Carlini, M., Faccenna, C., Ferranti, L., Gasperini, L., Govers, R.,

Klaeschen, D., Monaco, C., Neri, G., Nijholt, N., Orecchio, B., and Wortel, R.: The Ionian and

Alfeo-Etna fault zones: New segments of an evolving plate boundary in the central Mediterranean 
Solid Earth Discuss., https://doi.org/10.5194/se-2018-112

Manuscript under review for journal Solid Earth

Discussion started: 22 October 2018

712 Romano, S., Artoni, A., and Carlini, M. Lower plate serpentinite diapirism in the Calabrian Arc

713 subduction complex, Nat. Commun., 8(1), 2172, 2017.

Pondrelli, S., Piromallo, C., and Serpelloni, E.: Convergence vs. retreat in Southern Tyrrhenian Sea:

insights from kinematics. Geophys. Res. Let., 31(6), 2004.

717

Presti, D., Troise, C., and De Natale, G.: Probabilistic location of seismic sequences in heterogeneous media, Bull. Seism. Soc. Am., 94, 2239-2253, 2004.

720
Presti, D., Orecchio, B., Falcone, G., and Neri, G.: Linear versus nonlinear earthquake location and seismogenic fault detection in the southern Tyrrhenian Sea, Italy, Geophys. J. Int., 172, 607-618, 2008.

Presti, D., Billi, A., Orecchio, B., Totaro, C., Faccenna, C., and Neri, G.: Earthquake focal mechanisms, seismogenic stress, and seismotectonics of the Calabrian Arc, Italy, Tectonophysics, 602, 153-175, 2013.

Rebaï, S., Philip, H., and Taboada, A.: Modern tectonic stress field in the Mediterranean region: evidence for variation in stress directions at different scales. Geophys J Int, 110(1), 106-140, 1992.

Sani, F., Vannucci, G., Boccaletti, M., Bonini, M., Corti, G., and Serpelloni, E. Insights into the fragmentation of the Adria Plate, J Geodyn, 102, 121-138, 2016. 
Solid Earth Discuss., https://doi.org/10.5194/se-2018-112

Manuscript under review for journal Solid Earth

Discussion started: 22 October 2018

(c) Author(s) 2018. CC BY 4.0 License.

Serpelloni, E., Vannucci, G., Pondrelli, S., Argnani, A., Casula, G., Anzidei, M., Baldi, P., and Gasperini, P.: Kinematics of the Western Africa-Eurasia plate boundary from focal mechanisms and GPS data, Geophys J Int, 169(3), 1180-1200, 2007.

Splendore, R., and Marotta, A. M. Crust-mantle mechanical structure in the Central Mediterranean region, Tectonophysics, 603, 89-103, 2013.

Totaro, C., Presti, D., Billi, A., Gervasi, A., Orecchio, B., Guerra, I., and Neri, G.: The ongoing seismic sequence at the Pollino Mountains, Italy, Seismol. Res. Lett., 84(6), 955-962, 2013.

Totaro, C., Seeber, L., Waldhauser, F., Steckler, M., Gervasi, A., Guerra, I., Orecchio, B., and Presti, D.: An Intense Earthquake Swarm in the Southernmost Apennines: Fault Architecture from High-Resolution Hypocenters and Focal MechanismsAn Intense Earthquake Swarm in the Southernmost Apennines. Bull. Seism. Soc. Am., 105(6), 3121-3128, 2015.

Totaro, C., Orecchio, B., Presti, D., Scolaro, S., and Neri, G.: Seismogenic stress field estimation in the Calabrian Arc region (south Italy) from a Bayesian approach. Geophys. Res. Lett., 43(17), 8960-8969, 2016.

Wortel, R., and Spakman, W.: Subduction and slab detachment in the Mediterranean-Carpathian region, Science, 290, 1910-1917, 2000.

Wyss, M., Liang, B., Tanigawa, W.R., and Xiaoping, W.: Comparison of orientations of stress and strain tensor based on fault plane solutions in Kaoiki, Hawaii, J. Geophys. Res. 97, 4769-4790, 1992. 
Solid Earth Discuss., https://doi.org/10.5194/se-2018-112

Manuscript under review for journal Solid Earth

Discussion started: 22 October 2018

(c) Author(s) 2018. CC BY 4.0 License.

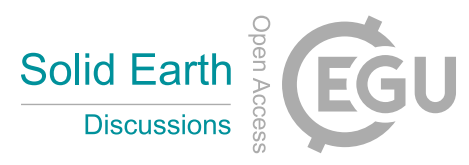

(c) (i)

761 Zoback, M.L.: First-and second-order patterns of stress in the lithosphere: the world stress map

762 project, J. Geophys. Res., 97(B8), 11 703-11 728, 1992.

763

764

765

766 
Solid Earth Discuss., https://doi.org/10.5194/se-2018-112

Manuscript under review for journal Solid Earth

Discussion started: 22 October 2018

(c) Author(s) 2018. CC BY 4.0 License.

Figures caption

Fig. 1. Simplified sketch map of the Africa-Eurasia plate boundary. Black arrows indicate the present-day sense of motion of Africa with respect to Eurasia according to Palano et al. (2015a). Abbreviations: $\mathrm{AP}=\mathrm{Apennines}, \mathrm{CA}=\mathrm{Calabrian}$ Arc, $\mathrm{MA}=$ Magrhebides. The dashed rectangle including southern Italy and relative off-shore sectors indicates the main area of interest in the present study (see Fig. 2). The top-left inset shows the western Mediterranean plate boundary evolution in the last 30 Myrs (redrawn from Wortel and Spakman, 2000, with modifications according to Neri et al., 2009). The solid curves with the sawtooth pattern indicate the location of the boundary at different times as a consequence of ESE-ward rollback of the WNW-ward subducting lithosphere. The sawteeth point in the direction of subduction or underthrusting. Black sawteeth indicate in-depth continuous subducting slab in contrast to white sawteeth marking plate boundary segments where slab detachment has occurred. The white arrow along the Apennines shows the inferred direction of lateral migration of slab detachment.

Fig. 2. Tectonic map of southern Italy and relative off-shore areas (redrawn from Palano et al., 2012, with integration of data in the Ionian Sea according to Polonia et al., 2011). Black arrows indicate the present-day sense of motion of Africa with respect to Eurasia according to Palano et al. (2015a). TFS stands for Tindari Fault System.

Fig. 3. Hypotheses of lithosphere fragmentation and microplate architecture proposed in the literature for the central Mediterranean region. (a) Simplified tectonic setting of the central Mediterranean region (redrawn from Cadet and Funiciello, 2004). (b) Main plate boundaries and Adria microplate contours according to Anderson and Jackson (1987). RP indicates the pole of rotation of Adria wrt Eurasia. (c) Macroplate and Adria representation in the view of Oldow et al.

792 (2002). (d) Adria separation in two independent blocks located between the main plates as reported 
Solid Earth Discuss., https://doi.org/10.5194/se-2018-112

Manuscript under review for journal Solid Earth

Discussion started: 22 October 2018

(c) Author(s) 2018. CC BY 4.0 License.

793 by Battaglia et al. (2004). (e) Sketch of the main tectonic and kinematic features in the central

794 Mediterranean (redrawn from Serpelloni et al., 2007). (f) Adria and Apulia-Ionian-Hyblean blocks

795 according to D'Agostino et al. (2008). (g-h) The two alternative scenarios proposed by Palano et al.

796 (2012): (g) the Ionian domain is rigidly connected with the Sicilian-Hyblean-Malta block; (h) the

797 Ionian domain diverges from the Sicilian-Hyblean-Malta block and moves together with the

798 Calabrian block. (i) According to Pérouse et al. (2012) a rigid single block including the Hyblean

799 Plateau, the Ionian basin, the Sirte plain, the Apulian peninsula and the southern Adriatic sea can be

800 hypothesized, rotating clockwise wrt Africa (the star indicates the rotation pole). (j) New reconstruction of Adria domain between the main plates according to Sani et al. (2016). Shaded

802 areas indicate uncertain limits among blocks.

803

Fig. 4. Section (a) displays the map of seismic stations used for hypocenter locations in the present study. The dashed rectangle indicates the study area for the earthquake locations reported in sections (b) to (d) of this figure. The continuous rectangles indicate the sectors Western Ionian (WI) and Sicily Channel (SC) where hypocenter locations were also performed by the Bayloc method

808 (the results are shown in Figs 6 and 7). The shadowed curved belt shows the approximate location of the Apennine-Maghrebian chain in south Italy and Sicily. Section (b) displays the epicentral map of earthquakes of magnitude over 2.5 that occurred between 1981 and 2016 at depths less than 100 $\mathrm{km}$ in the area $10^{\circ}-20^{\circ} \mathrm{E} 35^{\circ}-41^{\circ} \mathrm{N}$ (circles are proportional to the earthquake magnitude, see legend). For these locations we used the linearized location method known as Simulps (Evans et al.

813 1994) and the 3D seismic velocity structure proposed for the study region by Orecchio et al. (2011).

814 Sections (c) and (d) display the earthquakes of Section (b) after separation according to hypocenter depth (0-30 km and 30-100 km, respectively).

817 Fig. 5. Fault-plane solutions of earthquakes of magnitude over 2.5 occurring in the period $1977-$ 8182016 at depths less than $70 \mathrm{~km}$ in the area countoured by the dashed rectangle in Fig. 4. Only 
Solid Earth Discuss., https://doi.org/10.5194/se-2018-112

Manuscript under review for journal Solid Earth

Discussion started: 22 October 2018

(c) Author(s) 2018. CC BY 4.0 License.

solutions estimated by waveform inversion are reported. The main parameters and the bibliographic source of each solution are given in Table A1, Appendix A. The different colors in the figure identify different types of mechanisms following Zoback's (1992) classification based on values of plunges of $\mathrm{P}$ and $\mathrm{T}$ axes: red = normal faulting (NF) or normal faulting with a minor strike-slip component $(\mathrm{NS})$; green $=$ strike-slip faulting $(\mathrm{SS})$; blue $=$ thrust faulting $(\mathrm{TF})$ or thrust faulting with a minor strike-slip component (TS); black = unknown stress regime (U). "U" includes all focal mechanisms that do not fall in the other five categories (Zoback, 1992). The beach ball size is proportional to the earthquake magnitude (see legend). The curved line contours the study area for stress inversion (results in Fig. 8)

Fig. 6. (a-c-d) Epicentral maps obtained by the Bayloc probabilistic method for the earthquakes occurring during 1981-2016 in the sector WI, depth ranges 0-70 km (plot a), 0-30 km (plot c) and 30-70 km (plot d). For comparison, the structural information of Fig. 2 is reported. (b) Bayloc's hypocentral vertical section along the $\mathrm{AA}^{\prime}$ profile indicated in plot a, $+-70 \mathrm{~km}$ around the profile. AEF and IF stand for Alfeo-Etna Fault and Ionian Fault, respectively.

Fig. 7. (a-c-d) Epicentral maps obtained by the Bayloc probabilistic method for the earthquakes occurring during 1981-2016 in the sector SC, depth ranges 0-70 km (plot a), 0-30 km (plot c) and 30-70 km (plot d). For comparison, the structural information of Fig. 2 is reported. (b) Bayloc's hypocentral vertical section of earthquakes of plot (a) along a west-east profile.

Fig. 8. (a) Orientations of the principal stress axes (lower hemisphere stereographic projection) obtained by inversion of the earthquake focal mechanisms shown in map. Red, green, and blue dots

842 indicate the orientations of the maximum $(\sigma 1)$, intermediate $(\sigma 2)$, and minimum $(\sigma 3)$ compressive stresses, respectively. Crosses and squares indicate the $95 \%$ confidence areas for the $\sigma 1$ and $\sigma 3$ axes, respectively. $\mathrm{F}$ is the average of the individual earthquake misfits wrt the best model of stress 
Solid Earth Discuss., https://doi.org/10.5194/se-2018-112

Manuscript under review for journal Solid Earth

Discussion started: 22 October 2018

(c) Author(s) 2018. CC BY 4.0 License.

found by inversion (see text). (b) Stress inversion results obtained after subdivision of the study area in two sub-areas $\mathrm{W}$ and $\mathrm{E}$, west and east of the black line $\mathrm{AB}$, respectively. (c) Stress inversion results in the shadowed sector RZ where Polonia et al. (2017) have identified a rifting process with opening in the SW-NE direction, approximately. See Table 1 for numerical values of stress inversion results.

Fig. 9. This figure indicates the overall compressional domain caused by Africa-Eurasia convergence in southern Italy disturbed by (i) extensional processes in the Calabrian Arc, (ii) rifting in the westernmost Ionian offshore Sicily and (iii) subduction-related reduced compression in the trench retreat zone offshore eastern Calabria. Black-to-grey transition of GPS crustal motion vectors marks their clear orientation change from NW-ward to NE-ward and corresponds with the onshore prolongation of the Ionian NW-trending rifting zone (diverging arrows are taken from Polonia et al., 2017, GPS vectors are from Palano et al., 2012). Seismic data do not give significant information on stress regimes in the white field of the southern Tyrrhenian sea.

Table 1. Stress tensor inversion of earthquake focal mechanisms performed for the earthquake sets ALL, W, E and RZ described in the text and relative to the sectors indicated in Fig. 8. $\mathrm{N}$ is the number of earthquakes (= focal mechanisms) belonging to the inversion set. $\mathrm{F}$ is the average of the misfits of the individual earthquakes with respect to the best model of stress found by inversion. $\mathrm{R}$ is the amplitude ratio $(\sigma 2-\sigma 1) /(\sigma 3-\sigma 1)$ where $\sigma 1, \sigma 2$, and $\sigma 3$ represent the amplitudes of the maximum, intermediate and minimum compressive stress, respectively. $\mathrm{Pl}$ and $\mathrm{Az}$ are the plunge and azimuth, respectively, of the three main stress axes. 
Solid Earth Discuss., https://doi.org/10.5194/se-2018-112

Manuscript under review for journal Solid Earth

Discussion started: 22 October 2018

(c) Author(s) 2018. CC BY 4.0 License.

871 Table 1. Stress tensor inversion of earthquake focal mechanisms performed for the earthquake sets

872 ALL, W, E and RZ described in the text and relative to the sectors indicated in Fig. 8. $\mathrm{N}$ is the

873 number of earthquakes (= focal mechanisms) belonging to the inversion set. $\mathrm{F}$ is the average of the

874 misfits of the individual earthquakes with respect to the best model of stress found by inversion. $\mathrm{R}$

875 is the amplitude ratio $(\sigma 2-\sigma 1) /(\sigma 3-\sigma 1)$ where $\sigma 1, \sigma 2$, and $\sigma 3$ represent the amplitudes of the

876 maximum, intermediate and minimum compressive stress, respectively. $\mathrm{Pl}$ and $\mathrm{Az}$ are the plunge

877 and azimuth, respectively, of the three main stress axes.

878

\begin{tabular}{cccccccccc}
\hline Set & $\mathbf{N}$ & $\mathbf{F}\left({ }^{\circ}\right)$ & $\mathbf{R}$ & $\boldsymbol{\sigma 1} \mathbf{P 1}\left({ }^{\circ}\right)$ & $\boldsymbol{\sigma 1} \mathbf{A z}\left({ }^{\circ}\right)$ & $\boldsymbol{\sigma 2} \mathbf{P 1}\left({ }^{\circ}\right)$ & $\boldsymbol{\sigma 2} \mathbf{~ A z}\left({ }^{\circ}\right)$ & $\boldsymbol{\sigma 3} \mathbf{P 1}\left({ }^{\circ}\right)$ & $\boldsymbol{\sigma 3} \mathbf{A z}\left({ }^{\circ}\right)$ \\
\hline All & 72 & 8.3 & 0.5 & 3 & 320 & 76 & 217 & 14 & 51 \\
W & 32 & 5.9 & 0.5 & 3 & 150 & 84 & 275 & 5 & 60 \\
E & 40 & 8.3 & 0.5 & 3 & 319 & 75 & 216 & 15 & 50 \\
RZ & 27 & 6.5 & 0.4 & 64 & 162 & 25 & 345 & 3 & 79 \\
\hline
\end{tabular}

879 
Solid Earth Discuss., https://doi.org/10.5194/se-2018-112

Manuscript under review for journal Solid Earth

Discussion started: 22 October 2018

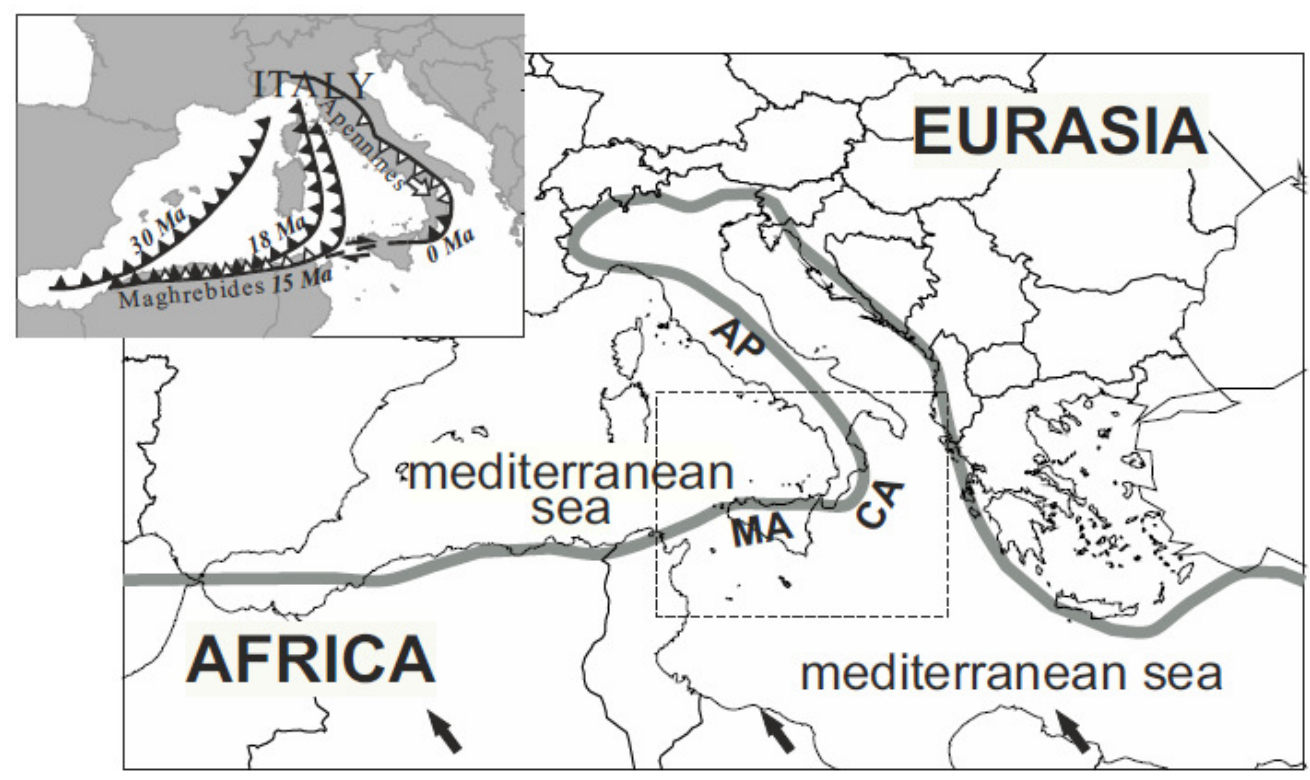


Solid Earth Discuss., https://doi.org/10.5194/se-2018-112

Manuscript under review for journal Solid Earth

Discussion started: 22 October 2018

(c) Author(s) 2018. CC BY 4.0 License.

(c) (1)

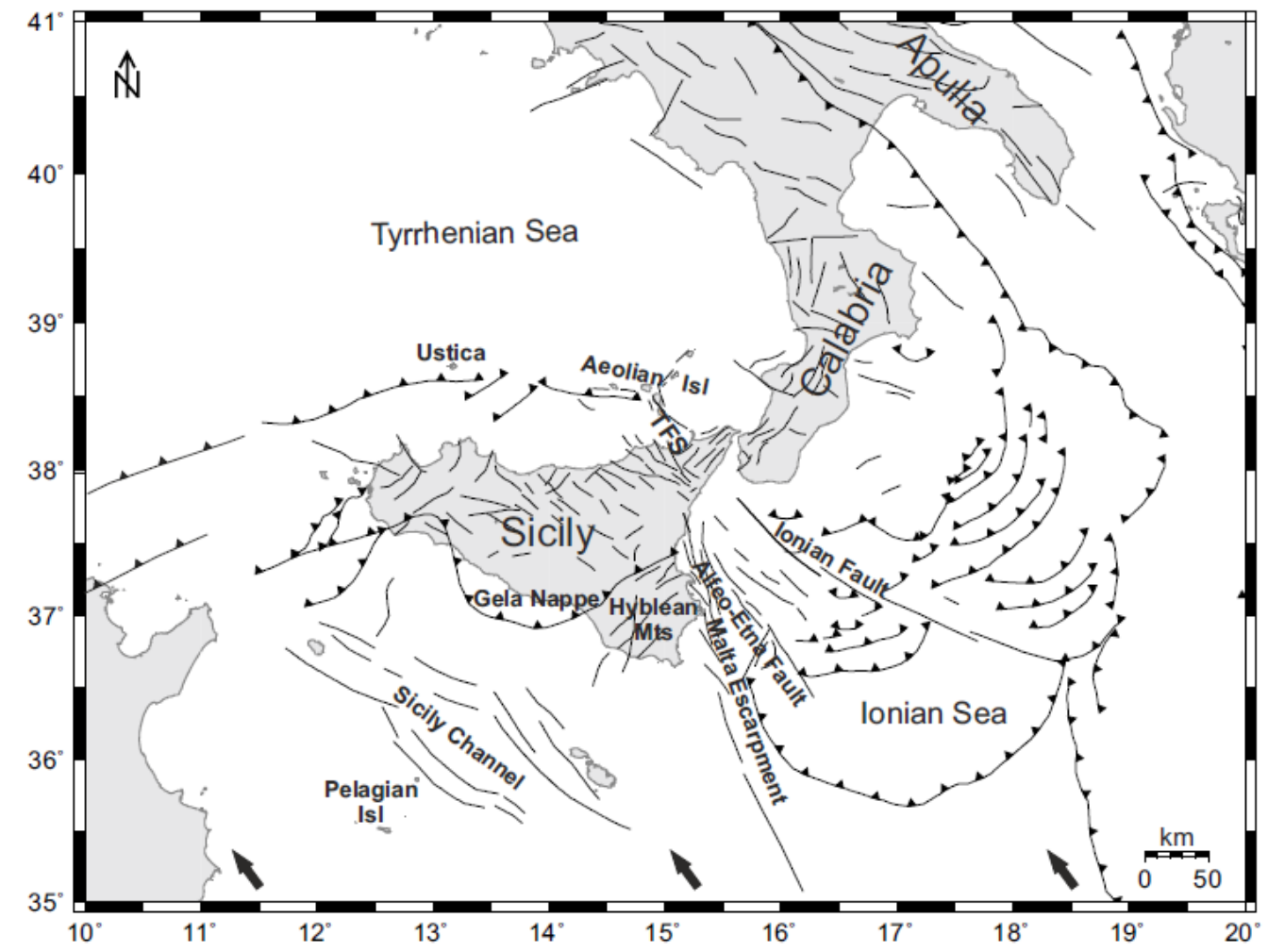


Solid Earth Discuss., https://doi.org/10.5194/se-2018-112

Manuscript under review for journal Solid Earth

Discussion started: 22 October 2018

Solid Earth

(c) Author(s) 2018. CC BY 4.0 License.
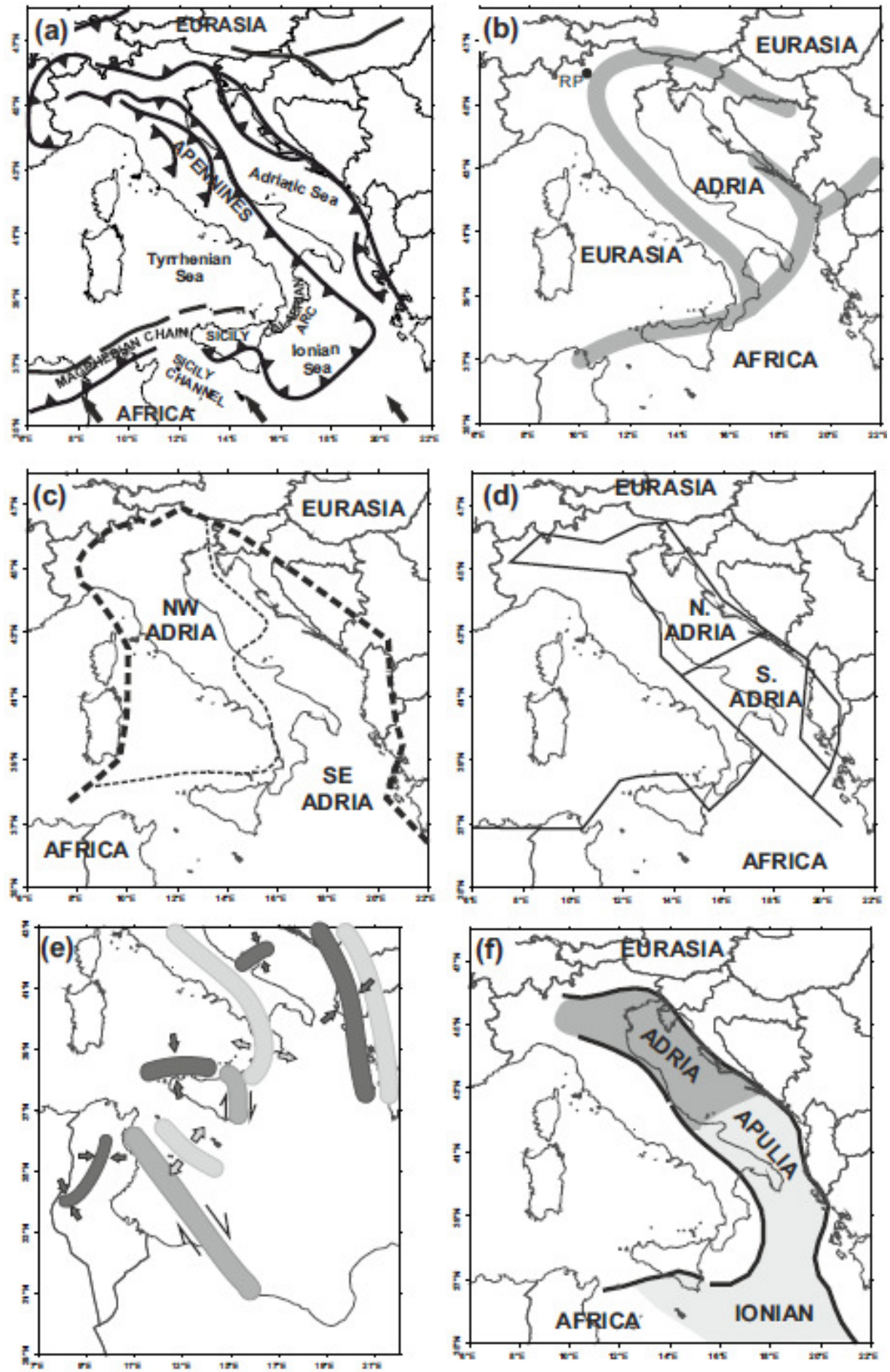
Solid Earth Discuss., https://doi.org/10.5194/se-2018-112

Manuscript under review for journal Solid Earth

Discussion started: 22 October 2018

(c) Author(s) 2018. CC BY 4.0 License.
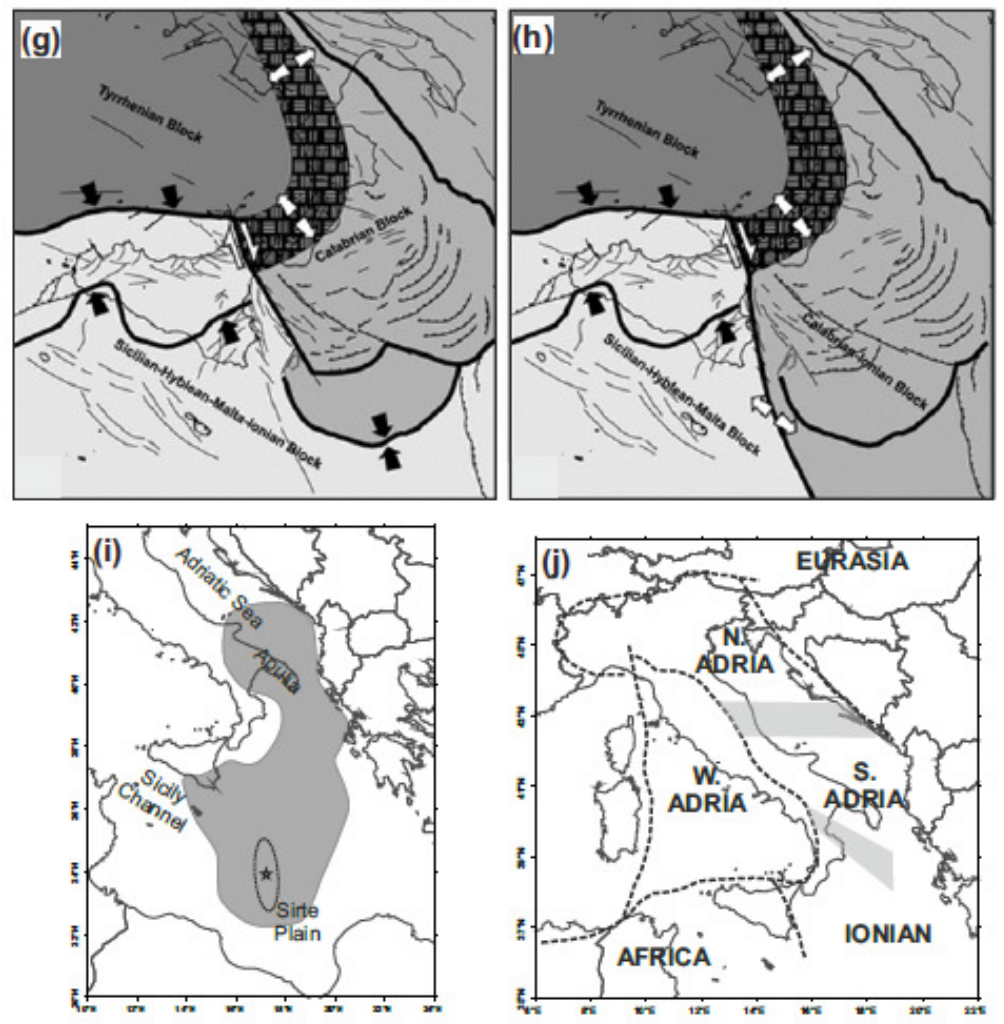

886

Figure 3 (continued) 
Solid Earth Discuss., https://doi.org/10.5194/se-2018-112

Manuscript under review for journal Solid Earth

Discussion started: 22 October 2018

(c) Author(s) 2018. CC BY 4.0 License.

(c) (1)
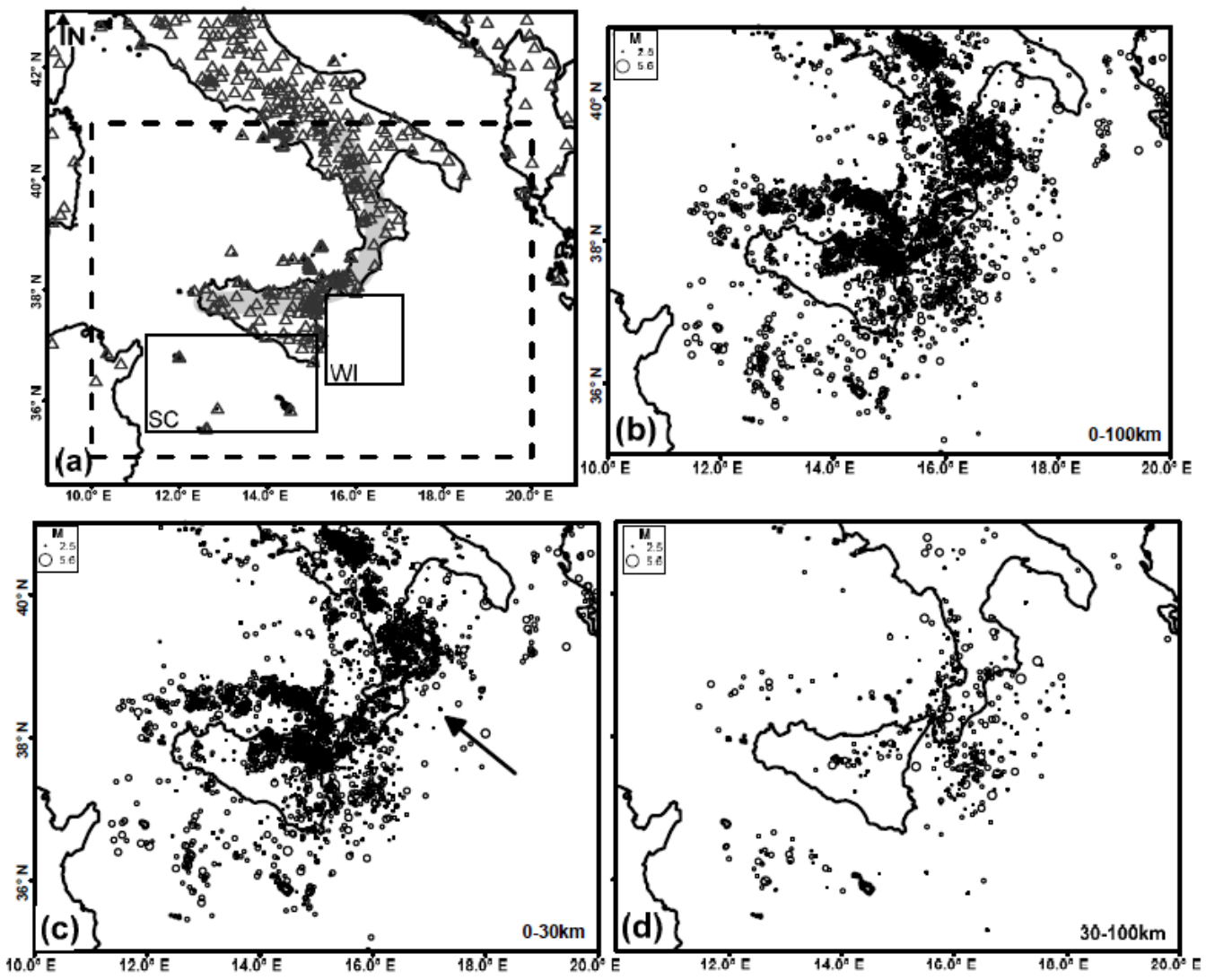
Solid Earth Discuss., https://doi.org/10.5194/se-2018-112

Manuscript under review for journal Solid Earth

Discussion started: 22 October 2018

Solid Earth

Discussions

(c) Author(s) 2018. CC BY 4.0 License.

(a) (1)

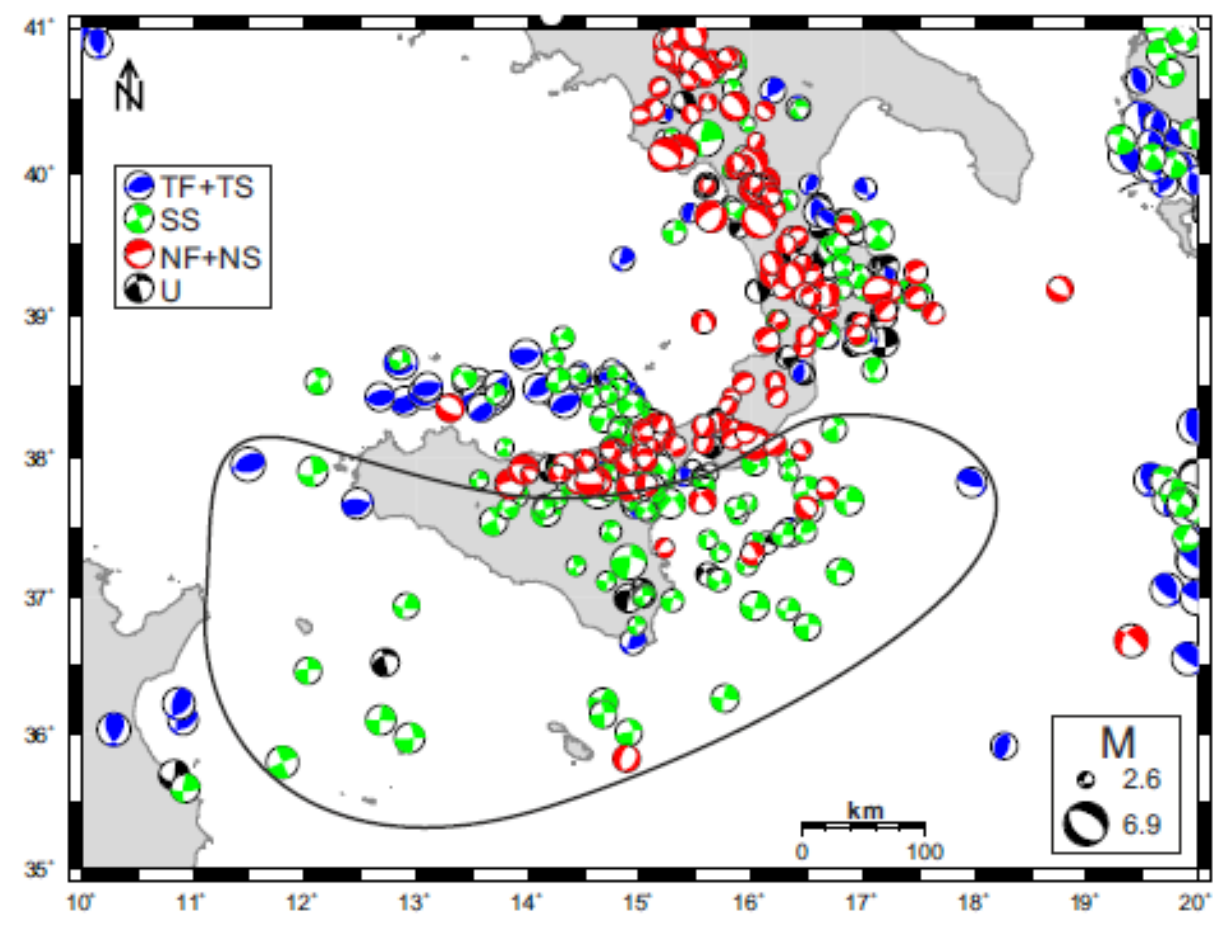

890

Figure 5

891 
Solid Earth Discuss., https://doi.org/10.5194/se-2018-112

Manuscript under review for journal Solid Earth

Discussion started: 22 October 2018

(c) Author(s) 2018. CC BY 4.0 License.
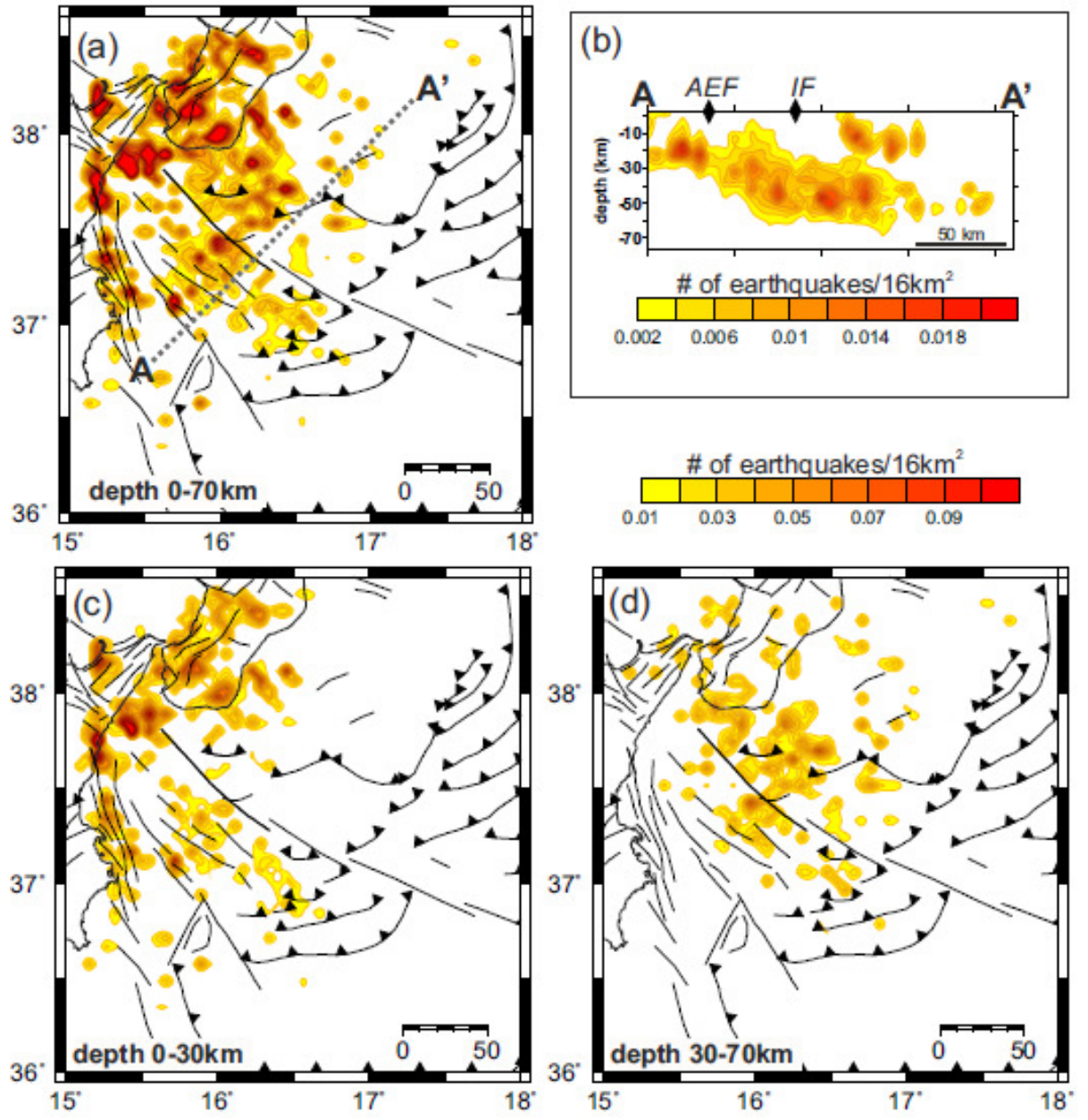
Solid Earth Discuss., https://doi.org/10.5194/se-2018-112

Manuscript under review for journal Solid Earth

Discussion started: 22 October 2018

(c) Author(s) 2018. CC BY 4.0 License.

(c) (1)
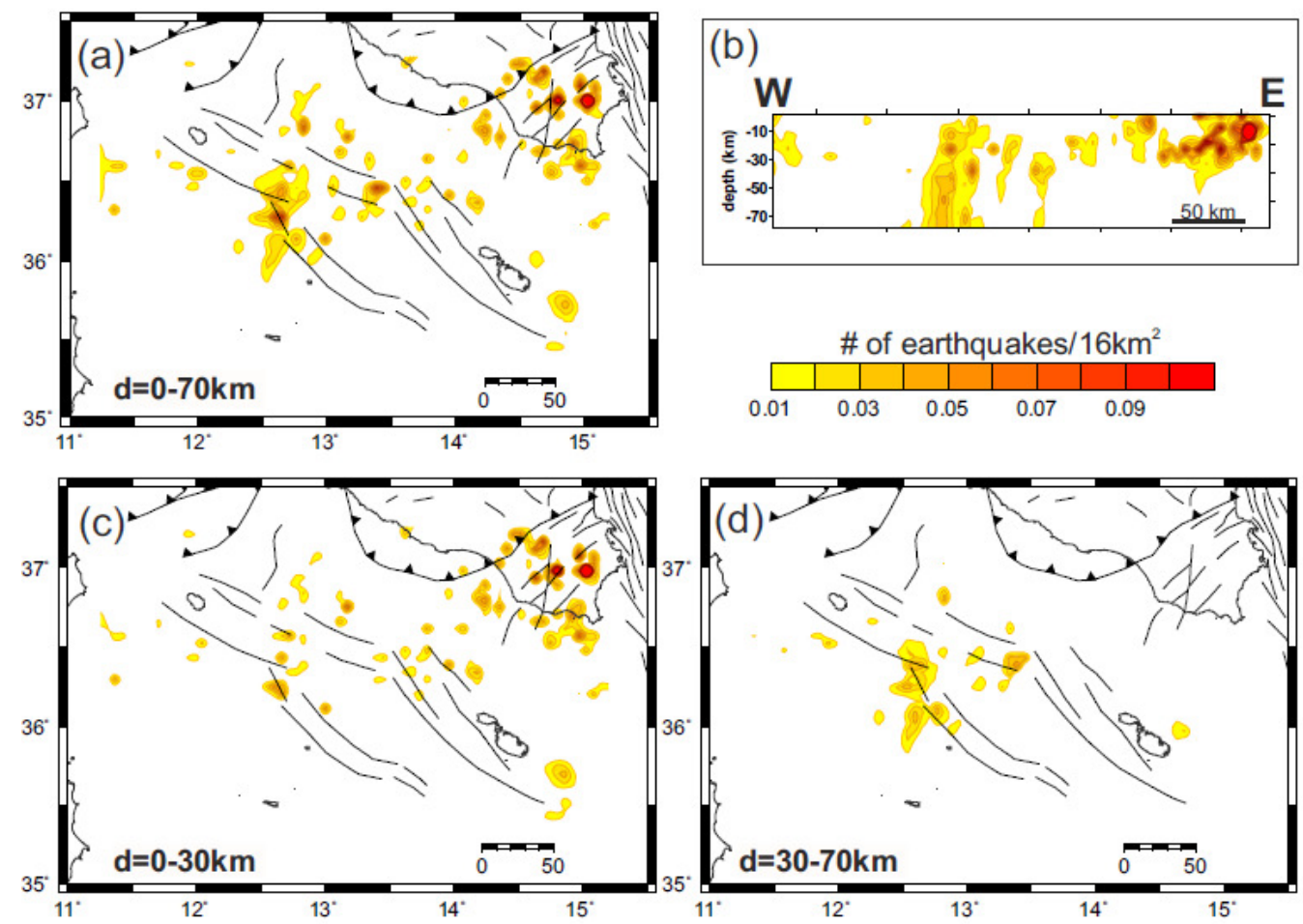

894

Figure 7 
Solid Earth Discuss., https://doi.org/10.5194/se-2018-112

Manuscript under review for journal Solid Earth

Discussion started: 22 October 2018

Solid Earth

(c) Author(s) 2018. CC BY 4.0 License.

(c) (1)
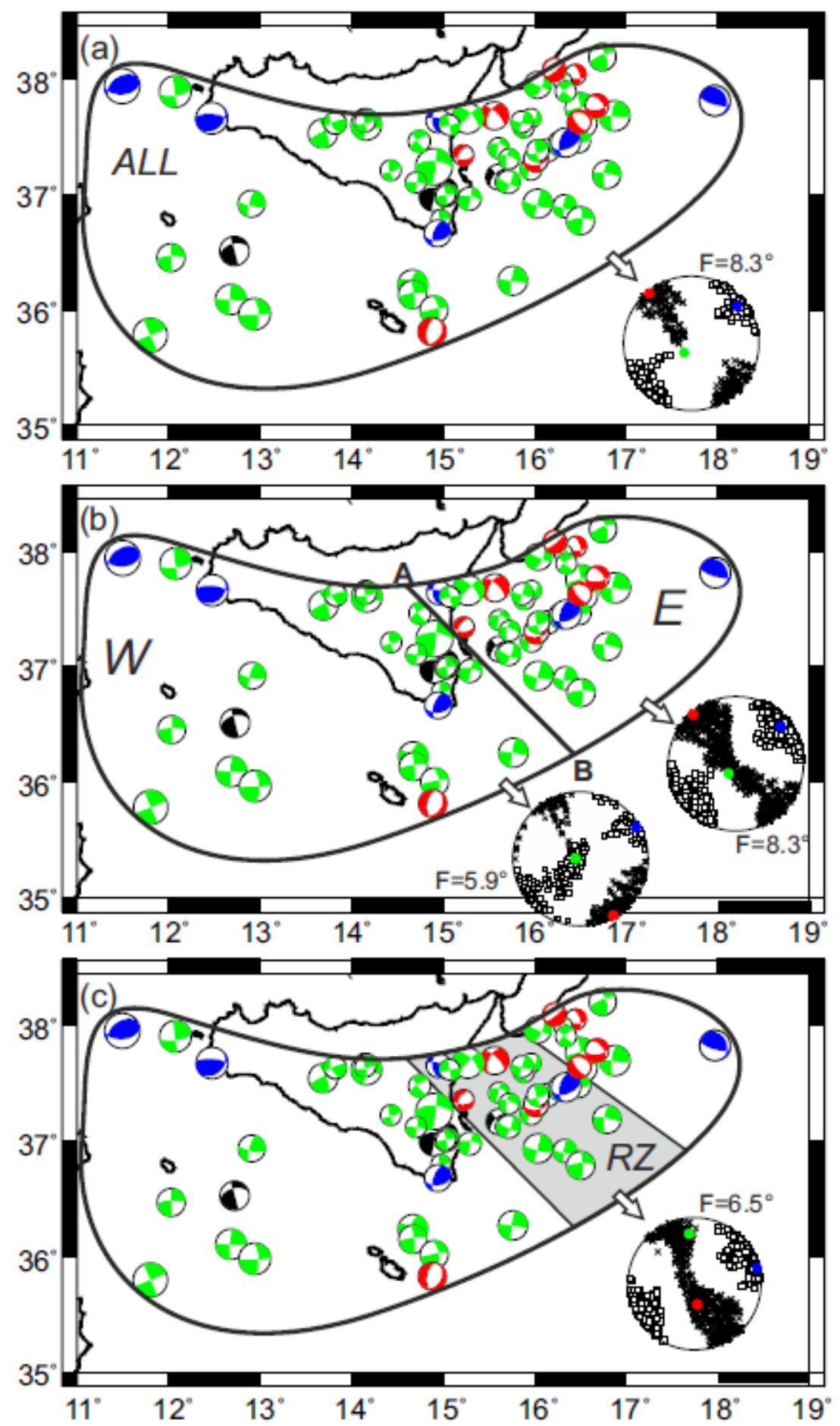

Figure 8 
Solid Earth Discuss., https://doi.org/10.5194/se-2018-112

Manuscript under review for journal Solid Earth

Discussion started: 22 October 2018

(c) Author(s) 2018. CC BY 4.0 License.

(c) (i)

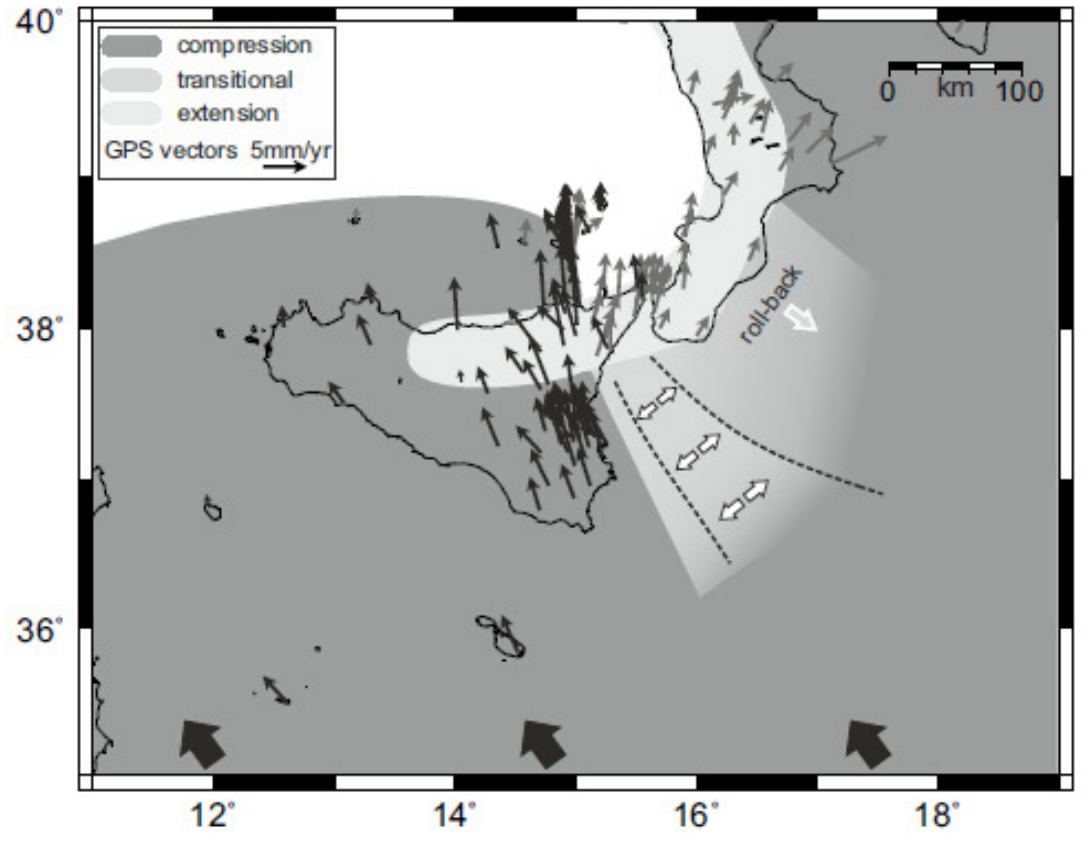

897

Figure 9 